Portland State University

PDXScholar

1974

\title{
Police Discretion with Respect to the Juvenile Offender, Department of Public Safety, Multnomah County, Oregon
}

Muriel Bridges

Portland State University

Monty Merritt

Portland State University

Follow this and additional works at: https://pdxscholar.library.pdx.edu/open_access_etds

Part of the Juvenile Law Commons, Law Enforcement and Corrections Commons, and the Social Work Commons

Let us know how access to this document benefits you.

\section{Recommended Citation}

Bridges, Muriel and Merritt, Monty, "Police Discretion with Respect to the Juvenile Offender, Department of Public Safety, Multnomah County, Oregon" (1974). Dissertations and Theses. Paper 1717.

https://doi.org/10.15760/etd.1716

This Thesis is brought to you for free and open access. It has been accepted for inclusion in Dissertations and Theses by an authorized administrator of PDXScholar. Please contact us if we can make this document more accessible: pdxscholar@pdx.edu. 
POLICE DISCRETION WITH RESPECT TO THE JUVENILE OFFENDER DEPARTMENT. OF PUBLIC SAFETY, MULTNOMAH COUNTY, OREGON

by

MURIEL BRIDGES and MONTY MERRITT

A report submitted in partial fulfillment of the requirements for the degree of

MASTER OF

SOCIAL WORK

Portland State University 1974 


\section{ACKNOWLEDGEMENTS}

This research was made possible with the help of many people. Unfortunately all of them cannot be named. The help they provided is, nevertheless, greatly appreciated.

We are deeply indebted to Director Bard J. Purcell of the Department of Public Safety, Multnomah County, Oregon, for allowing us to conduct this study. The financial and administrative support he offered made this study possible.

Appreciation is also expressed to all of the deputy patrolmen who cooperated in the research and filled out the questionnaire. Specifically, we are grateful to Patrolman Robert Barnhart for his assistance in the testing process.

We especially wish to acknowledge the tremendous debt of gratitude which is owed to Lieutenant Dennis Brand, Comnanding officer of the Youth Services Section, Department of Public Safety, Multnomah County, Oregon. Much of the success of this study is due to his assistance, guidance, encouragement, and friendship. Our association with Lieutenant Brand and the deputies assigned to Youth Services Section will long be remembered. 
TABLE OF CONTENTS

PAGE

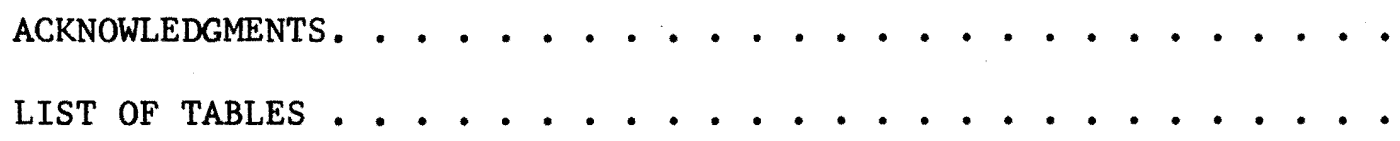

CHAPTER

I. INTRODUCTION .................. 1

The Problem. . . . . . . . . . . . 1

Police Discretion and the Juvenile. . . . 2

Lack of Formalized Criteria . . . . . 3

Background and setting ........... 7

The Department of Public Safety, Multnomah

County, Oregon............ . . 7

II. THE RESEARCH LITERATURE. . . . . . . . . . . 15

III. METHODOLOGY. . . . . . . . . . . . . . 26

Origin . . . . . . . . . . . . . 26

Study Objectives . . . . . . . . . . 27

Hypothesis of the Study. . . . . . . . . 27

Operational Definitions of the Study . . . . . 30

Selection of the "Sample" to be Studied. . . . 33

Characteristics of the "Sample". . . . . . 34

Measurement Instrument ........... 35 
Procedure of the Questionnaire......... 40

Focus of Section One .......... 41

Focus of section Two .......... . . 41

Focus of Section Three......... . 43

Results of Pre-Test ............ 43

Collection of the Study Data. . . . . . . 44

Tabulation and Statistical Analysis...... 46

IV. ANALYSIS OF THE DATA. . . . . . . . . . 48

V. CONCLUSIONS ..................... 73

Discussion. . . . . . . . . . . . 73

Recommendations............. 77

Limitations of the Study. . . . . . . . 78

BIBLIOGRAPHY. . . . . . . . . . . . . . . . . 81

APPENDIX I . . . . . . . . . . . . . . . . . 83

Questionnaire . . . . . . . . . . . . . . . 83 
LIST OF TABLES

TABLE

PAGE

1. Ranking of Information Categories According to Importance. . . . . . . . . . . . . . 50

2. Ranking of Information Categories in General as

Compared to Ranking of Information Categories in

Cases Presented.............. . . 52

3. Agreement between Philosophy and Practical Application. . 54

4. Agreement between Important Categories in Cases

Compared with the Five Listed Important Categories

in General................. . . 55

5. Number and Per Cent Judging Categories to be Among the

Top Three in Importance . . . . . . . . . . 58

6. Various Dispositions by Cases ............ 61

7. Categories of Personal Characteristics as They Relate to Juvenile Dispositions. . . . . . . . .

8. Number and Per Cent Choosing Various Dispositions in the Three Cases, by Shifts. . . . . . . . 
CHAPTER ONE

INTRODUCTION

THE PROBLEM

This is an exploratory study which focuses on the types of information that deputies assigned to the Department of Public Safety, Multnomah County, Oregon, consider important when making a decision regarding the disposition of a juvenile offender.

This empirical study developed as a result of participant observation. The authors spent one year working with deputies as part of police-social worker teams. During the course of the year it became apparent that police use a considerable amount of discretion when determining the disposition of a juvenile offender.

The purpose of this exploratory study was to investigate systematically: 1) the types of information that deputies believed play the most significant role in the decision-making process in general, 2) the types of information that deputies used when determining which disposition to apply toward a juvenile charged with a particular offense, 3) the personal and occupational characteristics of the individual deputy that might have had a bearing on the dispositions he applied toward a juvenile, 4) if there was agreement between the types of information deputies generally believed were important to disposition of cases and the types of information deputies actually utilized when making a decision in particular cases, 5) if there was agreement among officers with respect to the 
disposition of a juvenile in particular cases, and 6) the relationship among types of information deputies believed were important in particular cases, the dispositions they applied toward juveniles in that case and the nature of the case presented.

\section{Police Discretion and the Juvenile}

Law enforcement officers are the agents of the court who usually represent the first contact between the legal system and a youth. In the initial contact the officer decided whether the youth was seriously antisocial to the extent that he would interfere with the rights of others or be a threat to his own welfare or that of the community. The decisions made by officers determined whether or not a youth became involved in the Juvenile Justice System.

officers making decisions regarding juvenile dispositions are faced with multifaceted perspectives. The officer is expected to enforce the laws but at the same time he is also expected to take into consideration the welfare of the youth--that is, will it be more beneficial to the youth to impose legal sanctions upon him, or will it be more beneficial to release him with a warning? Interpreting and enforcing the laws designed for the protection of society, and at the same time applying the philosophy of the court, requires a great degree of sensitivity on the part of those entrusted with this double duty.

To accomplish the assigned dual task, the officer must depend upon the information that is available to him at the time of contact with the offender. All too often the quality and quantity of information is limited and sketchy. Specific information regarding psychsocial history is inaccessible to the officer. In most cases the officer has only 
"cues," such as attitude, age, sex, and physical or mental appearance of the subject, to assist him in arriving at a dispositional decision.

Agents of the court at the adjudicatory and postadjudicatory levels can allot extended periods of time to the collection of information pertaining to social variables which may be causative factors in the youth's behavior. The officer on patrol does not have the time to investigate these variables at length. The nature of his work prohibits this luxury. Consequently, he is compelled to draw upon his own resources and the information ascertainable at the time of contact when making a dispositional decision.

The very nature of the juvenile code contributes to the difficulties with respect to the use of discretion. Laws pertaining to juveniles are for the most part broadly stated. Therefore, when interpreting how the laws are to be applied, the officer must utilize his own selective, subjective discretion since the permissive language of legislation fails to act as a universal prescription.

Lack of Formalized Criteria

Central to the problem is the lack of formalized criteria for the use of discretion with respect to adults as well as to juveniles. This lack of criteria is directly related to the lack of recognition given to the extensive use of discretion which is exercised by the police regarding the enforcement of the law. Wayne R. LaFave has pointed out that:

as a general proposition, it can be said that the courts have seldom recognized the existence of invocation discretion in the police. In part this is due to the fact that strong language denying the existence of such discretion has been employed in many opinions where it is apparent a clear abuse of authority was involved. . . . Such language creates a sturdy barrier to "stare decisis," tending to preclude recognition, in later cases, of circumstances where discretion might have been validly exercised. . . . 
Because the exercise of discretion contemplates decision-making not strictly governed by legal rules, but rather with a significant element of personal judgement, it is sometimes said to be improper in an area such as criminal law enforcement where consequences of official action may directly affect a citizen's freedom and property. ${ }^{1}$

LaFave characterizes the dilemma for the police officer in terms of the statutes which prescribe circumstances under which arrests can be made without a warrant (e.g., strong suspicion) and how they have a duty to enforce all laws and to make arrests of all offenders if they are reasonably certain that persons are guilty of wrongdoing. However, the permissive language used in almost all arrest laws makes it difficult to be "reasonably certain" except by means of exercising discretion because criteria officially used in court precedents are related to given cases with either specific combination of circumstances. On the other hand, the officer is given little, if any, margin for error because he is subject to complete accountability for making false arrests. LaFave states:

Of central importance here is the question of how the ambiguity should be resolved at the arrest decision level. While a variety of positions may be taken, they would all seem to be somewhere between two extremes. On the one hand, it might be said that while the canon of strict construction and these other exacting interpretive devices are properly applied in court, they have no place at the arrest decision level. So viewed, the test for interpretation of ambiguous statutes, like that proof of guilt, would be broader at the arrest point than at the conviction stage; the process in both respects being one of a series of more and more selective decisions. The rationale for such an attitude (aside from the obvious point that otherwise some of the guilty would escape punishment) is that if the exact boundaries of a particular statute are to be better defined it is necessary for cases where doubt exists to reach a court of law. The contrary view is that the criminal law is to be interpretated strictly not only by the courts, but by the police as well. Implicit in this view is an attitude that the fair warning function of the law makes it improper for individuals who have engaged in conduct not clearly proscribed as criminal to be subjected to arrest, prosecution, and perhaps even conviction.

Of course, an officer's choices are not always merely those of noninvocation by way of strict construction or invocation by employing a broader interpretation. of ten it is possible for the 
officer, without arrest, to defer the interpretation question to another agency, such as the prosecutor's office, for a determination. However, as in the above illustration, the need for immediate arrest does not always make this possible. In such a case the policeman is left with the question of whether an arrest should be made when it is not entirely clear that the conduct is within the legislative proscription.

The answer may well be that the police for their own protection, are required to employ a very strict construction in doubtful cases. This is usually because some courts would hold that the officer, if brought to an accounting in false arrest action, has been left no room for error...

Thus the law requires "certainty" in place of "reasonable cause" in the relationship between the suspected conduct and substantive law. ${ }^{2}$

Although LaFave's remarks are made with reference to the discretion which police exercise when dealing with adult offenders, they are also appropriate for the use of discretion when the police are dealing with juvenile offenders LaFave reached several conclusions relative to the circumstances which accompany the use of police discretion:

-. . instances of police nonenforcement are of extremely low visibility and the means for challenge of specific instances of inaction are substantially limited. Thus, it should not be at all surprising that the law has seldom given recognition to either the existence or legitimacy of enforcement discretion in the hands of the police... ${ }^{3}$ (however)... The realities of current criminal justice administration make it imperative that the police exercise discretion in performing the law enforcement task; and, as the above discussion of current practice makes apparent, a broad range of discretion in fact has been assumed by police. 4

LaFave considers in his conclusion some of the problems associated

with the use of discretion when exercised by agents of the legal system.

He also gives some clue as to the manner in which he thinks changes might

improve the present system.

That the present system does and must include discretionary power raises the question of most serious nature. As Herbert Wechsler has written:

There are, of course, important differences between the law in action and the law in books in this and other fields. The soundest paper system would be totally impoverished by an 
inadequate administration, and sensible administration may get good results despite glaring defects in law. Abusive definitions of the scope of criminality may have their teeth drawn by agencies of prosecution in refusing to proceed . . . (But there is) no assurance that the possible correctives will be used in situations whereupon the merits they ought to be or that their applications will be principles and free from favor or abuse. A society that holds, as we do, to believe in law cannot regard with unconcern the fact that prosecuting agencies can exercise so large an influence on dispositions that involve the penal sanction, without reference to any norms but those that they create for themselves. Whatever one would hold as to the wisdom of attempting regulation of its exercise, it is quite clear that its existence cannot be accepted as a substitute for a sufficient law. Indeed, one of the major consequences of the state penal law today is that administration has so largely come to dominate the field without effective guidance from the law. This is to say that to a large extent we have, in this important sense, abandoned law--and this within an area where our fundamental teaching calls most strongly for its vigorous supremacy. 5

The need for discretionary enforcement, even at the police level, does not mean that law must be abandoned. Rather, there is as great a need for legal principles and legal controls governing nonenforcement as there is for such standards and sanctions in the area of affirmative criminal law enforcement. Whether offenders are subjected to the criminal process by means which are fundamentally unfair, or whether offenders are excluded from the process by resort to unsound criteria, the consequences to a democratic society are equally serious.

The first step is to elevate police discretion from the sub rosa position it now occupies; the role of the police as decision-makers must be expressly recognized. Then, as has been found possible with respect to other administrative agencies, the areas in which discretion properly may be exercised must be delimited, principles to govern its exercise must be established, and effective means of control must be discovered. Only then can it be said with certainty that police nonenforcement does not contravene some of our most cherished democratic values. ${ }^{6}$

To date, the use of discretion at the police level is an area of law enforcement that has been unattended to in the judicial system. Yet it is through this process that juveniles become labeled criminal or delinquent. LaFave and others have pointed out that the decision-making process at the police level does pose many problems. However, these problems must be recognized and dealt with if the legal system is to function as it is intended. 
Difficulty in interpreting broadly stated laws, community pressures, agency pressures and pressures from within the judicial system itself, complicates the decision-making process at the adult level. However, the process becomes more involved when the police officer is required to make a decision regarding a juvenile. In the case where a juvenile is involved, the deputy is not only obliged to contend with the difficulties mentioned above, but he must also take into consideration the welfare of the juvenile. In performing the decision-making task, the deputy is expected to satisfy everyone--the juvenile, his family, the community, the department, and the court. To date, however, there exists no formalized guidelines to assist the deputy in his monumental task.

The Department of Public Safety is aware of the difficulties concerned with decision-making. The Department is also aware of the need for empirical research in this area. Consequently, the Department wholeheartedly committed their support to this research project.

It is the hope of the authors that the results of this exploratory study will be beneficial to the Department in that it may assist them in developing further insights into how information influences decisions. Hopefully, this material will lead to the construction of formalized guidelines for decision-making which will aid the individual officer in his daily duties which involve the juvenile.

\section{BACKGROUND AND SETTING}

The Department of Public Safety, Multnomah County, Oregon

The law enforcement agency involved in this project was the Department of Public Safety, Multnomah County, Oregon. The geographic boundaries of the Department consist of the territory which begins at the city limits of 
Portland, and extends to the Oregon Counties of Washington, llood River, and clackamas. The 1970 census data revealed that the population was approximately 176,644 . The area is classified as suburban. The economic composition ranges from low-income to high-income families. The racial composition is predominantly white.

Prior to 1965, the Department of Public Safety was known as the Office of Multnomah County Sheriff. In 1965, the voters of Multnomah County passed "Home Rule." As a result, the Office of the Sheriff became a county department headed by a Director who is appointed by County Commissioners. Sheriff James C. Holzman was the first appointee in 1968. After Sheriff Holzman was dismissed by the County Commissioners in 1970, The Honorable Bard J. Purcell became Sheriff. He held this . position during the conduct of this study.

Since its inception in 1854, the Multnomah County Sheriff's Office has undergone many changes in organizational structure. Explanation of those changes is beyond the scope of this paper. At the time of this study, the Department of Public Safety was a hierarchically arranged bureaucratic organization. The total structure of the department is comprised of divisions which contain associated subdivisions.

The personnel in the Department are differentiated by rank. The Director is responsible for the operation of the total organization. Officers with the rank of captain are in charge of the functioning of a division. Lieutenants are responsible for the operation of subdivisions. Each subdivision has sergeants assigned to assist lieutenants in carrying out allotted subdivision functions. Deputy patrolmen work within each subdivision. The number of deputies assigned to a subdivision varies throughout the Department. 
To perform its prescribed duties, the Department of Public Safety employs a staff of approximately four hundred twenty-nine men and women. of this number, two hundred thirty-three are commissioned deputies. The remaining number of personnel are utilized in various other staff positions.

Prior to 1939, a staff member could be hired or fired upon the discretion of the Sheriff. In 1930, after the Civil Service Law was passed, the responsibility for the hiring and firing of the Sheriff Department employees became a task of the Civil Service Commission. This method of selection and rejection of staff members continues to date.

At the time this study was conducted, eligibility for selection as a commissioned deputy required that the applicant had earned a bachelor's degree from an accredited college or university. This requirement is not subject to waiver. Aside from the basic degree requirement, the candidate must successfully complete five steps in the examination process before being accepted as a deputy patrolman.

Step One consists of successfully completing a rigid written and oral civil service examination with a score of seventy-five or higher. The written portion of the examination is designed to test the logical reasoning ability of the candidate. The oral interview is designed to measure such things as maturity, interest, background, confidence, and other traits the Department believes a candidate should possess. Step Two entails a psychological evaluation administered by staff psychologists. This phase of the testing process is designed to reveal any traits that would seriously impair an applicant's ability to perform as a police officer. The battery of tests include the M.M.P.I., the Edwards, and the Rorschach. 
In Step Three, applicants who managed to successfully complete the first two phases are expected to appear before a selection committee. The permanent selection committee includes the Commander of Personnel and Training Section and those commissioned officers on his staff. In this in-depth oral interview, the applicant's performance under stress is evaluated.

Step Four involves a standard, thorough physical examination.

The applicant is not directly involved in Step Five. This portion of the testing process consists of a background investigation of the candidate's credit rating, driving record, employment history and personal references.

The final step in the processing of a candidate involves a personal interview with the Director of the Department. It is he who makes the final decision regarding acceptance of a candidate. His decision is based upon the information compiled in Steps one through Five and his interview with the candidate.

Once an applicant becomes a staff member, his training as deputy sheriff begins. For twenty-one weeks, he attends the police academy. He is then expected to serve as a recruit. While serving as a recruit, the deputy rotates from section to section within the Department. This rotation process affords the recruit deputy an opportunity to gain an understanding of each section's function.

The rationale behind the rigorous examination and training period is to maintain a Sheriff's Department that effectively serves the total community.

The deputies' education and training in police work does not stop after the deputy has completed all of the required criteria for becoming 
an officer who may work independently. Deputies are encouraged to take additional academic courses in disciplines directly or indirectly related to the law enforcement field. Deputies are often dispatched to national seminars which pertain to law enforcement. The Department believes that the knowledge the officer brings back and shares with the staff members will assist it in performing its role in the community more effectively. From its initial, unsophisticated beginnings, the Department of Public Safety has developed into what Wilson defines as a "professional law enforcement agency." Wilson states:

A "professional" police department is one which is run on the basis of universalistic value standards which are derived from a set of general, impersonal rules which bind all members of the organization and the relevance which does not depend on particular circumstances of time, place or personality. A nonprofessional department (what I shall call later a "fraternal" department), on the other hand, relies to a greater extent on particularistic value judgements--i.e., judgements based on the significance to a particular person of his particular relations to particular others. The professional department looks outward to its externally valid, enduring standards; the non-professional department looks, so to speak, inward, at the informal standards of the group and distributes rewards and penalties according to how well a member conforms to the expectation of the group.

The specific attributes which are consistent with these definitions include the following:

(1) A professional department, to a greater extent than a nonprofessional one, recruits members on the basis of achievement rather than ascriptive criteria. More concretely, it relies to a much greater extent on standardized, formal entrance examinations which are open to all eligible persons, regardless of where they may live. Thus, the professional department not only recruits impartially without reference to political connections or racialreligious identities, it recruits without regard to whether the candidate is a local resident. Non-professional departments of ten insist (or the law requires them to insist) on recruitment only from citizens of the local community. Educational standards are typically higher for entrance to professional departments. For all these reasons, professional departments tend to have a higher proportion of "cosmopolitans" as opposed to "locals."

(2) Professional departments treat equals equally; that is, laws are enforced without respect to persons. In such departments, "fixing" traffic tickets is difficult or impossible and the sons of the powerful are not likely to be given preferential treatment. Non-professional departments have a less formal sense of justice, 
either because of the system of which they are a part encourages favoritism, or because (and this is equally important) officers believe it is proper to take into account personal circumstances in dispensing justice. Concretely, we may expect to find a less difference in the professional department between the proportion of white and nonwhite juvenile offenders who are arrested rather than giving warnings or reprimands.

(3) Professional departments are free of graft and corruption and their cities will be freer of "tolerated" illegal enterprises (gambling, prostitution), than is the case with non-professional departments.

(4) Professional departments place heavy emphasis on formal training and indoctrination as a way of instilling universalistic standards in members and generating a commitment to them. In this training there will be considerable emphasis on the writing and teaching of "experts" (i.e., on carriers of universalistic and professional norms). In non-professional departments, there is less formal training and the training that is accomplished is done by departmental officers who embody particularistic norms and who stress "how to get along" on the force.

(5) Within the professional department, authority attaches to the role and not to the incumbent to a greater extent than in non-professional departments. The essentially bureaucratic distribution of authority within the professional force is necessary because, by relying on achievement criteria, young officers are of ten promoted rapidly to positions of considerable authority (as sergeants and lieutenants in both line and staff bureaus). 7

\section{Working for a "professional" department allows the individual}

officer to be more objective when making disposition decisions. The relatively high wages eliminate the need for accepting graft. Once hired, the deputy does have a considerable degree of job security. This sense of security allows him to perform his role relatively free of the threat of being discharged upon the whim of some official. In turn, he can make decisions which are based upon how he interprets the situation rather than on how the officials higher up would interpret the situation. His education and training have offered him a solid foundation for performing his assigned duties.

In striving for "professionalism" the Department of Public Safety strives for objectivity. It is also very much interested in assessing how well they achieve their objectives. This study is an indication of 
their eagerness to evaluate, through research, existing department practices related to the decision-making process with respect to juveniles.

The literature reveals that other police agencies across the country, as well as many criminologists and sociologists, are devoting increased attention to the decision-making process at the police level. The next chapter focuses upon some of the literature pertaining to decision-making. 


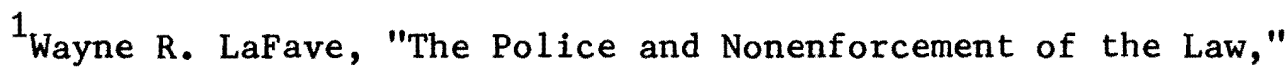
Wisconsin Law Review, January, No. 1, 1962, pp. 105, 184.

${ }^{2}$ Ibid., pp. 189-190.

${ }^{3}$ Ibid., pp. 197.

${ }^{4}$ Ibid., pp. 238.

${ }^{5}$ Herbert Wechsler, "The Challenge of Model Penal Code," Harvard Law Review, Vol. 65, 1952, pp. 1097, 1101-1102.

${ }^{6}$ LaFave, op. cit., Note 2, pp. 238-239.

${ }^{7}$ See Robert L. Peabody, "Perceptions of Organizational Authority; A Comparative Analysis," Administrative Science Quarterly, Vol. VI, March, 1962, pp. 477-480. The entire quote was taken from James Q. Wilson, "The Police and the Delinquent in Two Cities" (unpublished manuscript), p. 25. 
CHAPTER TWO

THE RESEARCH LITERATURE

The juvenile codes of each state outline the legal criteria for determining when a juvenile's behavior should receive the attention of the court. The juvenile code is the major framework within which discretion is exercised by police officers. In addition, police officers are provided directives in the form of departmental regulations and policies which are somewhat unique to their respective police departments. An example of departmental directives indicating the criteria to be used by the officers when dealing with juveniles is the following statement from the Chicago Youth Division:

The regulations of the Chicago Police Department require that when a male, under the age of seventeen, comes to the attention of any member of the Department, the youth must be interviewed and processed by a Youth officer. The responsibility for the proper initial disposition of such a case rests entirely with the Youth officer. In those instances where a juvenile's action constitutes a hazard to himself or others without an actual breach of the law or where a present admonition may serve to prevent a future crime, the juvenile is officially warned. In addition, the parents of the individual are fully informed of the incident and the dangers involved.

When an unlawful action is committed by a juvenile, a Youth Officer has three alternatives of action. These are the "station adjustment," "referral to the Family Court," and "detention in the Audy Home for Children." When considering which course of action to take the Youth officer carefully weighs the following criteria:

1. The nature and seriousness of the offense.

2. The juvenile's behavioral history--both official and unofficial.

3. The juvenile's physical and mental characteristics and an estimate of the amount and nature of treatment services which may be required. 
4. The attitudes of the parents towards their child and the offense committed as well as their ability to control and discipline the child.

5. The attitude and rights of the complainant. 1

The Children's Bureau suggests that a complete police investigation be conducted before recommending a disposition on a juvenile offender. This investigation would include:

1. Facts of the offense, including all details necessary to sustain a petition in court.

2. Record of any previous police action.

3. Record of any previous court or social agency action.

4. Attitudes of the child, his parents, and the complainant in the offense, toward the act.

5. Adjustment of the child in home, school and community. 2

A conference of chiefs of police established the following criteria as justification for juvenile court referral:

1. The particular offense committed by the child is of a serious nature.

2. The child is known or has in the past been known to the juvenile court.

3. The child has a record of repeated delinquency extending over a period of time.

4. The child or his parents have shown themselves unable or unwilling to co-operate with agencies of a non-authoritative social agency) character.

5. Casework with the child by a non-authoritative agency has failed in the past.

6. Treatment services needed by the child can be obtained only through the court and its probation department.

7. The child denies the offense and the officer believes judicial determination is called for, and there is sufficient evidence to warrant referral or the officer believes that the child and his family are in need of aid.

8. There is apparent need for treatment. ${ }^{3}$ 
Dennis C. Sullivan and Larry J. Siege ${ }^{4}$ undertook a study involving three police departments within the same metropolitan area in the northeastern United States. The study sought a systematic examination of the decision-making process of police regarding juvenile offenders.

An information or decision board was the testing instrument used in the study. This testing instrument was developed by Leslie Wilkins. 5 The testing instrument allowed the participants (twenty-four policemen) to use information under the simulation of a real-life, police-juvenile encounter, allowing tight experimental controls. The simulated situation involved a juvenile charged with drunk and disorderly conduct, with each officer recording the amount and types of information he used in reaching a decision.

The results show that these policemen use an average of five pieces of information before making a decision, with the less experienced officers using twice as much information as their experienced colleagues. The experienced officers, as a group, were not only less deliberative but most all agreed on the same disposition--arrest. offense and age were the pieces of information most of ten selected first and second, respectively. But attitude of offender appeared to be the piece of information selected just prior to making a decision, establishing its critical importance. Race was not a significant factor.

Piliavin and Briar ${ }^{6}$ studied discretion in a metropolitan police department. Their findings established the following: (1) Policemen use discretion when dealing with youthful offenders; (2) There are observable criteria which affect their use of discretion; these include previous record, race, grooming and demeanor (demeanor, the youth's attitude towards the law, the police and his own criminal behavior, was 
the major factor in deciding whether or not to refer the juvenile to court; (3) The arrest of more blacks than whites was a consequence of police bias and black youths showing poor demeanor more of ten than white youths when confronted by police. Furthermore, because of the high crime rates in black areas police spent more time patrolling such areas. Blacks who were regarded as potential law violators and who were frequently stopped without cause demonstrated increasing hostility toward police who considered their poor demeanor as justification for accosting them.

McEachern and Bauzer ${ }^{7}$ have found that various individual characteristics of the juvenile influence the officer's decision to file a petition. These characteristics include sex, age, previous record, family status, and probation status. In addition, such factors as the nature of the offense, and the police department policies also influence the officer's decision to file a petition. Further, holding offense constant, these variables interact in such a way as to eliminate the effects of family, status, ethnicity and sex; to reduce the effects of previous record and probation status and to maintain the effect of age. Again, holding offense constant, the police department policies and the individual officer significantly affect requests for court petitions. McEachern and Bauzer concluded that delinquency can best be described as the interaction between deviant individuals and community agents who define deviant behavior, and not as simply acts of bad people.

After doing research on various communities in the Pittsburgh area, Nathan Goldman ${ }^{8}$ has shown that juvenile offenders who were ordered to appear in court were chosen by a process of differential selection. Among his findings are the following: (1) the percentage of juveniles 
arrested who were also referred to the juvenile court varied antong communities; (2) arrested juveniles who commit serious offenses are more often referred to the court than are arrested juveniles who commit minor offenses; (3) variances in the court referral rates among communities exist because minor offenses are handled in a different manner; (4) arrested black children are subject to court referral more often than are arrested white children; (5) court referral rates for black juvenile offenders vary among the communities; (6) frequent court referrals of black children for minor offenses account for most of the variance in the referral rates of arrested black children among the communities; (7) police are more likely to refer girls than boys to juvenile court; (8) court referral rates on arrested children increase with the age of the child; (9) patterns for handling juvenile offender cases exist within the different communities and are reflected in the arrest and referral rates; (10) police attitudes towards the offender and his family, the offense, the juvenile court, his role as policeman, and community attitudes toward delinquency all influence the policeman's differential selection of offenders for court.

George E. Bodine ${ }^{9}$ found that there is a correlation between the disposition a juvenile offender receives from the police and the income level of the area where he lives. But, with respect to large cities, having police youth bureaus, it was hypothesized that this relationship was dependent on three other variables--the juvenile offender's age, previous record, and offense committed. While age was not directly related to disposition, he found that previous record was closely related to both disposition and income level. Further, first offenders were differentially selected for court referral by the police. He explained 
that differential selection was related to the income level of the arca

and not the juvenile's race. In conclusion Bodine states:

In the absence of multiple regression analysis, it is not possible to determine fully how much of the relationship between income area and police disposition can be accounted for by the selected factors of this study. The data suggest.. . Juveniles from low-income areas have a higher referral rate to court than juveniles from high-income areas for two reasons: low-income youth are more of ten apprehended as repeating offenders, and repeating offenders have a referral rate which is twice as great as the rate for initial offenders; low-income youth have a higher arrest rate for petty theft and petty thieves in general, and lowincome petty thieves in particular have a high court referral rate. 10

Wayne R. LaFave ${ }^{11}$ has written about the nature of discrimination as

it pertains to differential law enforcement. He states:

Discrimination, or what might be called discrimination, may take many forms in law enforcement. One possibility, of course, is that members of minority groups may be arrested or perhaps carried even further on in the process though they are guilty of no criminal conduct; this quite obviously, is improper. A second possibility is unequal enforcement of the law with respect to minority groups in the sense that laws generally not enforced are enforced against minority groups. This, of course, is a serious matter, particularly since it is not likely that the arrested offenders will be able to prevent having the process invoked against them on this basis. A third possibility is the failure to enforce certain laws only against members of certain minority groups. The dilemma . . . put is that the Negro continues to be judged by a different standard because he lives by a different standard, and he continues to live by a different standard because he is judged by a different standard.12

Wattenberg and Bufe $\mathrm{e}^{13}$ conducted a study on officers assigned to the

Detroit Youth Bureau. They found that the continued delinquency of a juvenile first offender was highly dependent on the manner with which the juvenile was handled by the individual youth service officer, and that the officer's manner could be predicted by the officer's individual characteristics.

All of these studies mention a variety of variables which influence the fate of a juvenile who has been confronted by a law enforcement 
officer. These variables include personal characteristics of the juvenile, such as age, sex, race, and attitude as well as personal characteristics of the police officer, such as attitude and work style. Also included among the variables are the social status and family income of the juvenile. In addition there are the expectations, either real or implied, from the officer's department and from the community in which he works that he carry out his police work in a certain manner.

LaFave, 14 Piliavin and Briar, 15 and Goldman 16 all emphasized the existence of racial discrimination by police in the handling of juvenile offenders. They found that the behavior of black juveniles consistently received closer scrutiny by the police than did the behavior of white juveniles. Black juveniles were stopped more frequently than white juveniles, often for minor or rarely enforced laws, and if taken into custody their cases remained "active" for longer periods of time.

Bodine $^{17}$ also emphasized the existence of discrimination in police work but he identified the victims as juveniles belonging to the lower class.

All of these studies seem to suggest that police decision-making behavior with respect to juveniles varies between police departments. Also suggested is that police decision-making behavior disregards what should be the principal criteria for taking a juvenile into custody, towit: the perceived need for rehabilitation and the seriousness of the offense, as recommended by Myren and Swanson, 18 and the President's Commission on Law Enforcement and Administration of Justice.19

These studies have identified specific kinds of information which are used in police decision-making. But few of these studies have been 
able to evaluate how much information is used in any one police-juvenile encounter. In addition, methods of collecting the hard data for most of these studies on police decision-making behavior have not been based on an examination of the police-juvenile encounter, either in real-1ife or in a simulated "real-1ife" situation, providing for the necessary experimental controls. But rather these studies have relied on the use of police and court records for the hard data.

The one study which is a departure from previous studies is that of Sullivan and Seigel.20 In their study they used a methodology which provided for the necessary degree of experimental control and, at the same time, simulated the real-life use of information. They got experienced police officers to describe the types of information generally used in a police-juvenile encounter. They constructed a contrived case, using this information. They then plugged the case information into the Wilkins ${ }^{21}$ testing instrument. This allowed them to collect their data on information handling under proper experimental controls.

We also wanted to examine the decision-making process as it occurred between police officer and the juvenile. We used a panel of experienced officers to describe types of information. It is at this point that we deviated from the Sullivan and Siegel 22 methodology. We decided not to use the Wilkins Information Board because it was too rigid of a testing instrument and because it was economically unfeasible for the desired sample size.

We knew that within each information category there is a range of variations, i.e., with sex either male or female; with age from age 10 or younger to age 18 ; with attitude from positive to negative. In order to capture some of the variations within each information category we decided 
to use not one but three contrived cases. And we decided to present the three cases as narratives of typical police-juvenile encounters. This approach allowed the testee to examine each case as a total experience before analyzing the case for the purpose of making decisions on a disposition and on the importance of the information used.

With our study we hoped to produce findings which might be used to improve police decision-making behavior. These findings could provide information for the improvement of police training programs and for the modification of police policy. Of course, the findings of our study could produce hypothesis for further study. 


\section{NOTES}

\section{${ }^{1}$ Chicago Police Youth Division, Statement of Activities, 1960. p. 4.}

${ }^{2}$ Police Service for Juveniles, Children's Bureau Publication No. 344 , U.S. Government Printing Office, Washington, D.C., 1954, pp. 7-10.

${ }^{3}$ Ibid., p. 20.

${ }^{4}$ Dennis C. Sullivan and Larry J. Siegel, "How Police Use Information to Make Decisions, An Application of Decision Games," Crime and Delinquency, Vol. 18, No. 3, July, 1972. (Note: The Sullivan and Siegel study provided the writers of this paper with a conceptual framework for developing the methodology used in their study.)

${ }^{5}$ Leslie T. Wilkins, Social Deviance (Englewood Cliffs, N. J.: Prentice-Hall, 1965), pp. 294-304.

${ }^{6}$ Irving Piliavin and Scott Briar, "Police Encounters with Juveniles," American Journal of Sociology, Vol. LXX, September, 1964, pp. 206-214.

${ }^{7}$ A. W. McEachern and Riva Bauzer, "Factors Related to Disposition in Juvenile Police Contacts," in Malcolm W. Klein and Barbara G. Myerhodd, eds., Juvenile Gangs in Context: Research, Theory, and Action, University of Southern California, Youth Studies Center, Conference Report, 1963, pp. $192-210$.

${ }^{8}$ Nathan Goldman, The Differential Selection of Juvenile Offenders for Court Appearance, National Research and Information Center and National Council on Crime and Delinquency, 1963.

${ }^{9}$ George E. Bodine, "Factors Related to Police Dispositions of Juvenile Offenders," Syracuse University, Youth Development Center (paper read at the annual meetings of the American Sociological Association, Montreal, Canada, August, 1964).

${ }^{10}$ Ibid., pp. 11-12. 
${ }^{11}$ Wayne R. LaFave, "The Police and Nonenforcement of the Law," Wisconsin Law Review, Vol. No. 2, March, pp. 179-239.

${ }^{12}$ Ibid., p. 208.

${ }^{13}$ William W. Wattenberg and Noel Bufe, "The Effectiveness of Police Youth Bureau Officers," Journal of Criminal Law, Criminology, and Police Science, December, 1963, pp. 470-475.

${ }^{14}$ LaFave, Supra Note 11.

${ }^{15}$ Piliavin and Briar, Supra Note 6.

${ }^{16}$ Goldman, Supra Note 8 .

${ }^{17}$ Bodine, Supra Note 9.

${ }^{18}$. Myren and Lynn Swanson, Police Work with Children (Washington: U.S. Government Printing office, 1962).

${ }^{19}$ President's Commission on Law Enforcement and Administration of Justice, Task Force Report: Police (Washington: U.S. Government Printing office, 1967), pp. 144-204.

${ }^{20}$ Sullivan and Siegel, Supra Note 4.

${ }^{21}$ Wilkins, Supra Note 5.

${ }^{22}$ Sullivan and Siegel, Supra Note 22. 
CHAPTER THREE

METHODOLOGY

\section{ORIGIN}

For one year, researchers of this study were participant observers working with deputies of the Department of Public Safety, Multnomah County, Oregon, as part of deputy-social worker teams. During the year it was apparent that deputies exercise a considerable amount of discretion and take into consideration many types of information other than the offense itself in order to arrive at a disposition with respect to juvenile offenders. Many dispositions are automatic because of regulations concerning objective criteria, such as age, sex, and severity of offense. However, a number of dispositions are based upon the deputy's interpretation of the types of information that are ascertainable to him at the time of the encounter with a juvenile. This information is related to the youth himself rather than the offense he has committed (with the exception of more serious offenses).

Toward the end of the year that we were with the Department, the Commanding officer of the Youth Services Section expressed a desire for research on how officers make their decisions and what influences these decisions. Consequently, with the approval and assistance of the Department of Public Safety, the researchers decided to conduct an exploratory study which would identify the types of information and the related dispositional decisions that deputy patrolmen in this law enforcement agency most frequently utilize in encounters with juveniles. 


\section{STUDY OBJECTIVES}

During the spring of 1973 , the objectives of this study were formulated. These objectives were to investigate systematically:

1) The types of information deputies believed are generally most important in the decision-making process with respect to juveniles, 2) The types of information deputies used when determining which disposition to apply toward a juvenile in a particular case, 3) To investigate if there was agreement between the types of information deputies believed were generally important to the disposition of cases and the types of information they actually utilized when making a dispositional decision in particular cases, 4) To investigate if there was agreement among officers with respect to the disposition of particular cases, 5) To investigate if a rerelationship existed among types of information, dispositions applied, and the nature of the case, 6) To investigate if personal and/or occupational characteristics of the deputy had an influence on the disposition he applied toward a juvenile.

\section{HYPOTHESIS OF THE STUDY}

Based upon the above objectives of the study, the following null hypotheses were developed. The hypotheses were not stated in alternate form because of the exploratory nature of the study.

I. Hypothesis I:

There is no significant difference between information categories with respect to their general importance. 
A. Assumptions.

1. Deputies do use various types of information when making

a decision with respect to disposition of juveniles.

2. These types of information can be described by the deputies.

3. These information categories are recognized by the deputy patrolmen in the District Patrol Section of the Operations Division and the Youth Services Section of this Department.

II. Hypothesis II:

There is no significant difference between the ranking of general information categories and the ranking of information categories in particular cases.

A. Assumptions.

1. Some types of information are considered more important than others in the decision-making process.

2. The nature of the case influences the relative importance of the types of information.

III. Hypothesis III:

There is no agreement between the information categories which are professed to be used by deputies and the information categories which are actually used by deputies in the cases presented.

A. Assumptions.

1. The deputy in a professional police department operates under a general philosophy.

2. To some measurable degree, the deputy in a professional police department applies the general philosophy to actual practice. 
IV. Hypothesis IV:

There is no difference in the importance of information categories offense, attitude of suspect, attitude of parent, mental health of suspect and previous record, as compared to chance in the cases presented.

A. Assumptions.

1. Types of information have relative value in particular cases.

2. The nature of the case influences the relative value of the information category.

V. Hypothesis V:

There is no significant difference among officers as compared to chance with respect to dispositions in the three cases presented.

A. Assumptions.

1. Deputies are given a limited number of dispositions which they can apply towards juveniles.

2. Dispositions are understood by deputies.

3. Dispositions are dictated by policy.

VI. Hypothesis VI:

There is no significant relationship between age of deputy and the disposition he applies toward a juvenile.

VII. Hypothesis VII:

There is no significant relationship between number of years in police work and the disposition the deputy applies toward a juvenile.

VIII. Hypothesis VIII:

There is no significant relationship between married and single deputies and the dispositions they apply toward juveniles. 
IX. Hypothesis IX:

There is no significant relationship between deputies who have children and deputies who do not have children and the disposition applied toward a juvenile.

A. Assumptions for Hypotheses VI, VII, VIII, IX.

Personality characteristics of the individual deputy have an impact upon how he interprets ascertainable types of information in contacts with juveniles, and this interpretation affects how he enforces the law.

$\mathrm{X}$. Hypothesis $\mathrm{X}$ :

There is no relationship between shift worked and disposition applied toward the juvenile offender.

A. Assumption.

The time period covered by shift and the association with other deputies working that shift have an influence upon the way the deputy assigned to that shift enforces the law.

\section{OPERATIONAL DEFINITIONS OF THE STUDY}

The following list will interpret the meanings of terms that will be used in this study:

1. Deputy patrolmen--Individuals who hold positions with the Department of Public Safety, Multnomah County, Oregon, and have the rank of patrolman. While on duty deputy patrolmen are required to engage in interaction with the community, to answer citizens' request for assistance, and to enforce the laws proscribed by Multnomah County and the State of Oregon.

2. Juvenile--Any person who is under the age of eighteen. 
3. Information category--a type of information.

Information categories in this study are:

a. Offense--a violation of the Oregon Juvenile Code.

b. Attitude of offender--verbal and/or nonverbal behavior of youth toward the committed offense, the investigating officer or other authority figures.

c. Age--a person who is under eighteen years of age and considered a juvenile.

d. Sex--male or female.

e. Time during shift--time refers to beginning, middle or end of a deputy's working day.

f. Shift--shift refers to specific working periods; i.e., First Shift, 11 P.M. until 8 A.M.; Second Shift, 7 A.M. until 4 P.M.; Third Shift, 3 P.M. until 12 A.M.

g. Location of offense--public or private property.

h. Attitude of parent--parental behavior regarding the offense, the deputy or other authority figures, and the youthful offender.

i. Appearance--general condition of clothes, hair. (Length of hair and style of wearing apparel were not considered to be important.)

j. Mood of the deputy--positive or negative attitude of deputy at time of contact with the juvenile.

k. Previous record--first or repeat offender.

1. Victim involved--the offense involves an injury to a person or it involves the destruction of a victim's property.

m. Onlookers present--the offender initially contacted in the presence of an uninvolved audience. 
n. Peer associations--reputation of known peer group, or attitudes of peers present at the scene of deputy's encounter with the juvenile offender.

o. Number of suspects--the number of youth involved in the offense.

p. Local resident--a youth who resides within the geographic boundaries served by the Department of Public Safety.

q. Concealed weapon--a hidden instrument which could be used to inflict injury.

$r$. Mental health of suspect--psychologoical functioning of the juvenile.

4. Contrived cases--events surrounding a typical police-juvenile encounter simulated by researchers to depict a real-1ife situation.

5. Positive attitude--the juvenile, the parents of the juvenile and peers of juvenile showed remorse and concern for offense committed; they were polite and cooperative in their responses to the deputy's questions.

6. Negative attitude--the juvenile, his parents and the juvenile's peers showed no concern or remorse for the offense committed; they were hostile and rebellious in their responses to the deputy's questions.

7. Neutral--the juvenile, the parents or peers of the juvenile were indifferent to or confused by the situation.

8. Disposition--the action that may be taken by the deputy against a juvenile who has committed an offense.

Dispositions available to the deputy are:

a. Warn and release at the scene.

b. Release to parents without writing a custody report. (Custody report implies that some further action will be taken.) 
c. Write a custody report and release juvenile on the scone with follow-up notification to parents.

4. Write a custody report and release juvenile to parents at his home.

5. Write a custody report and release juvenile to parents at Operations Division Headquarters.

6. Take into physical custody and transport to a counseling agency of the court.

7. Take into physical custody and transport to Juvenile Court.

\section{SELECTION OF THE "SAMPLE" TO BE STUDIED}

There is a wide variety of sheriff's departments in the state of Oregon and there are a great number of deputies. The deputies for this study were selected from one agency mainly because of the problem of access. The writers had access to the Department of Public Safety, Multnomah County, Oregon. The Department of Public Safety engages and specializes in all of the function that are considered an integral part of police work. For example, they are actively engaged in juvenile work, investigation of criminal offenses, training, crime laboratory work, patrol and corrections.

In terms of practical considerations it was extremely convenient to use the Department of Public Safety because of the location of their headquarters in Portland. In addition, the writers had the advantage of having personal acquaintances with Command officers. It was with their approval and cooperation that this research was made possible.

Deputy patrolmen who are assigned to the District Patrol Section of Operations Division and Youth Services Section of Investigation Division are the officers who usually have encounters with juveniles. Therefore, 
the researchers decided to draw a "sample" from these two sections of the Department. In order to obtain a random sample, researchers acquired a list of the names of the ninety-one deputy patrolmen assigned to District Patrol Section and the seven deputy patrolmen assigned to Youth Services Section. The sample was selected in the following manner. While one researcher assigned each deputy on the list a number from 00 to 98 , the other researcher selected fifty numbers from a table of random numbers. Deputies who had been assigned the first forty numbers which appeared in the table of random numbers became the study population. The remaining ten deputies were held in abeyance to be used as alternates in case selected deputies could not participate in the study.

The sample population consisted of forty deputy patrolmen. Since this number reflected approximately forty-one per cent of the deputy patrolmen assigned to District Patrol Section and Youth Services Section, researchers felt it was representative of these two sections.

During off-duty hours forty questionnaires were distributed to groups of deputies at Operations Dividion Headquarters and Youth Services Section office. Only one hour was necessary to complete the questionnaire. Respondents were paid overtime rates for their off-duty participation in the study.

\section{CHARACTERISTICS OF THE "SAMPLE"}

The median age of the deputies in the sample was twenty-seven. Experience in police work ranged from less than one year to fifteen years. The median number of years in police work was three. Thirty deputies in the sample were married; one was divorced and eight were single. Among the thirty married deputies, twenty had from one to four children. The 
median age of the children was 3.5. Thirty-five of the deputies had earned a bachelor's degree. Four of the remaining deputies have completed at least one year of college. Twenty-three of the deputies have undertaken graduate work. One patrolman has a master's degree. All members of the sample have completed the twenty-one-week Police Academy Training School.

Aside from the sample, the researchers requested the services of a deputy patrolman who would act as research assistant in the testing process. The researchers believed that deputies might be more receptive to the experiment if it were delivered by a member of their own profession rather than by a social worker. Also, using a deputy to administer the study helped to increase the credibility of anonymous responses and thus insured validity.

A deputy patrolman for the Youth Services Section had participated in the pre-test; he was familiar with the questionnaire and test procedures; he was acquainted with most of the personnel in the District Patrol Section. He consented to be research assistant. To prevent contamination of the study he was not made aware of which deputies were selected for the sample.

\section{MEASUREMENT INSTRUMENT}

Researchers originally intended to use the testing device designed by Leslie Wilkins and used in the previously mentioned Sullivan and Siegel study. ${ }^{1}$ (This device was explained in Chapter Two.) However, this device proved to be economically unfeasible for the sample size desired for this study and it did not get to all of the data we were interested in collecting in this study. Therefore, it became apparent that a new study 
technique had to be developed. The testing device had to contain a simulated encounter which depicted a typical encounter between a deputy and a juvenile. It had to yield quantifiable data pertaining to the types of information utilized by deputies when making a related dispositional decision. It had to reveal certain personal and occupational characteristics of the deputy.

Over a three-month period, the questionnaire in Appendix I was constructed. Formulation of the questionnaire was based upon the study objectives outlined above.

In formulating the questionnaire, the researcher's first concern was to identify the types of information which deputies considered important in the decision-making process. The data pertaining to types of information was needed to construct simulated cases. Researchers intended to incorporate the types of information utilized in the decisionmaking process into the cases they constructed and used in the questionnaire. This data was also needed to determine which types of information were considered generally important in decision-making, and to determine if agreement existed between the types of information deputies claim were generally important and the types of information that they utilized when making a dispositional decision toward a juvenile in the simulated cases. Since it is the deputies who are the principals in the decisionmaking process, the researchers decided that it should be they who determined which types of information were the most important in the decisionmaking process. To establish what these types of information were, Department Command officers selected a panel of five deputy patrolmen who were assigned either to the District Patrol Section or the Youth Services 
Section. Members of this panel were selected on the basis of their expressed diverse attitudes toward juveniles.

The panel convened on three occasions. Each meeting continued for three hours. During these sessions, panel members discussed the various types of information which they deemed crucial in the decision-making process with respect to juvenile dispositions. The panel agreed that the following information categories were important in reaching a decision regarding what to do with a juvenile coming under scrutiny in the field. Information categories were: offense, attitude of suspect, age, sex, time during shift, shift, location of offense, attitude of parent, appearance, mood of deputy, previous record, victim involved, onlooker present, peer association, number of suspects, local resident, concealed weapon, mental health of suspect.

After establishing the types of information which deputies considered important, the authors contrived three cases. Each case was contrived to exemplify a typical deputy-juvenile encounter. The eighteen information categories outlined above were incorporated into the contrived cases, but the characteristics of the types of information varied among the three cases. Variations of the characteristics were developed not only to lend variety to the cases, but variations were developed in order to establish the effect that variations in the nature of a particular type of information had upon dispositions. For example, we wanted to determine if a deputy applied a similar disposition toward a juvenile if the juvenile's attitude was positive as he applied toward a juvenile whose attitude was negative or neutral.

The information category, offense, was held constant across the contrived cases, because the nature and severity of offense is directly 
proportional to the amount of discretion which can be utilized by the deputy. That is, a deputy would not have discretionary privileges if a youth were charged with armed robbery or murder. However, in cases where the offense was criminal mischief, discretionary privileges may be extensively employed. Therefore, criminal mischief was selected as the offense.

The Oregon Revised Statutes give the following definition of the Criminal Mischief offense:

Criminal Mischief is intended to cover the type of misconduct that is not thievery but rather amount to tampering or unauthorized interference with the property of another. No damage need to be shown to use this charge. The person commits the crime of Criminal Mischief In The Third Degree ${ }^{2}$ if with the intent to cause substantial inconvenience to the owner or other person, and having no right to do so or reasonable ground to believe that he has such right, he tampers or interferes with the property of another. Criminal Mischief In The Second Degree ${ }^{3}$ occurs if the accused intentionally damages the property of another or recklessly damages property causing damage in excess of $\$ 100$. A person commits the crime of Criminal Mischief In The First Degree 4 if with the intent to damage property, the damage exceeds $\$ 1,000$, or, if it occurs by means of explosives. 5

Each contrived case reflected a degree of Criminal Mischief. In contrived Case One the offense was Criminal Mischief In The Second Degree. In contrived Case Two the offense was Criminal Mischief In The Third Degree. In contrived Case Three the offense was Criminal Mischief In The First Degree.

As participant observers on patrol with deputies, the researchers had many experiences which involved juveniles. However, we believed that the contrived cases should be examined to determine their validity. Isolated from one another, panel members were simultaneously requested to individually review and evaluate the completed contrived cases on the basis of their similarity to real-life encounters with juveniles. According to 
each panel member, none of the cases nor any aspect of the cases required revision. The contrived cases, in their opinions, reflected real-life encounters with juveniles.

The necessity for keeping cases strictly confidential was impressed upon the panel members. They agreed to comply with our request not to reveal case contents. To prevent contamination of the study, panel members were not informed of the other aspects of the study. They were cognizant neither of the focuses of the study nor the questionnaire portions of the project.

In addition to securing the types of information important to dispositions and contriving the cases, it was necessary to obtain the dispositional alternatives available to the deputies. The Commanding officer of the Youth Services Section supplied the researchers with this information. Dispositional alternatives permit the officer only to:

1. Warn and release at the scene.

2. Release to parents without writing a custody report.

3. Write a custody report and release juvenile on the scene with follow-up notification to parents.

4. Write a custody report and release juvenile to parents at home.

5. Write a custody report and release to parents at operations Division Headquarters.

6. Take into physical custody and transport to a counseling agency of the court.

7. Take into physical custody and transport to Juvenile Court.

Dispositions One and Two are the least severe measures that may be applied to a case situation. In dispositions Three, Four, and Five, the deputy elects to release the suspect, but the writing of a custody report 
insures that a follow-up investigation either by deputies of the Youth Services Section or by Juvenile Court officers will be made. When dispositions Six and Seven are applied, the juvenile is taken from the home (1) for his own protection, or, (2) to insure that he will receive treatment, or (3) when the nature of the offense requires that drastic action be taken.

Disposition alternatives were placed after each case. The deputy in the sample was requested to first read the case, then select which disposition he would apply if he were the deputy involved with the juvenile and to go on and list the three information categories which he considered had the most influence upon his dispositional decision.

The literature indicates that personal and occupational characteristics of the police officers often have an impact upon dispositions. Therefore, researchers determined to establish those characteristics which may be most influential to decision-making. Command officers were consulted. They advised the researchers that age, marital status, number of children, number of years in police work, the shift a deputy works and education were the variables they believed had an impact upon dispositions applied toward a juvenile.

On the basis of the advice given by Command officers, a portion of the questionnaire was devised to elicit from the deputies in the sample information pertaining to the above characteristics.

\section{PROCEDURE OF THE QUESTIONNAIRE}

Having verified 1 ) the types of information deputies believed were important in the decision-making process in general, 2) that the contrived cases reflected real-1ife encounters with juveniles, 3 ) the dispositional 
alternatives available to deputies, and 4) those personal and occupational characteristics which may influence decisions, researchers constructed the questionnaire contained in Appendix 1. The questionnaire was used as the testing device for the study. It was designed specifically to yield quantifiable data which could be statistically analyzed.

The questionnaire was divided into three sections. Each section was developed to obtain specific material relevant to the objectives of this study. The following is a clarification of the focuses of each of the sections contained in the questionnaire. Focus of Section One

Section One was designed to establish statistically whether results of the tests were associated with the variables under study rather than with personal or occupational factors of an underlying or suppressive nature.

Persons are sometimes hesitant to answer such questions, if in doing so they reveal their identity. Therefore, the variables "name" and "address" were not included in this or any section of the questionnaire. Focus of Section Two

Deputy patrolmen must make dispositional decisions within a very limited time frame. They are not afforded the luxury of delay in decisionmaking. After reading the contrived case, the deputies were asked to signify which of the listed dispositions in Part A that they would apply to the subject involved. The data collected in Part A ascertained the relationship between disposition and personal or occupational characteristics, ascertained the degree of consistency that existed in the sample with respect to selected dispositions, and ascertained whether or not dispositions varied according to the situation. 
To establish the importance of each category as they related to each contrived case, the deputy was asked to rate each listed information category in Part B as High, Medium, or Low as it applied to each case.

Part $\mathrm{C}$ was designed to investigate five specific research areas: 1. To investigate which information categories weighed most heavily in the deputy's dispositional decision, 2. To investigate whether information categories used to make decisions varied from situation to situation, 3. To investigate the degree of agreement among deputies with respect to the selection of information categories utilized in the decision-making process, 4 . To investigate whether there was agreement between what deputies believed were generally important information categories and the information categories which they actually used when they made a decision in a specific case, and 5 . To investigate if there was a patterned relationship between the type of information utilized and the applied disposition.

The possibility exists that information categories other than those listed might contribute to a deputy's decisions. Part D provided space for the listing of any such category. Analysis of the data revealed that no deputy utilized this space though they were orally solicited for the addition of unsuggested categories.

A confidence scale was developed for Part E. This scale was devised to establish the degree of certainty with which the deputy finally arrived at his decisions. The range of the scale is from Number 1 to Number 10 . Number 1 indicates a total lack of confidence while Number 10 indicates total confidence in the decision chosen. 
Focus of Section Three

The panel members selected eighteen categories they deemed significant to the disposition of cases in general, but the members of the panel were not requested to indicate the importance of each category selected. This task was assigned to the sample of deputies selected for the test. To determine the ordinal importance of information categories, deputies were requested in Section Three to select ten of the listed eighteen information categories and rank these 1 through 10 in spaces allotted on the questionnaire. The deputies were informed that giving an information category the rank of Number 1 indicated that he believed this category was the most important type of information generally utilized in the dispositional decision-making process, while giving a category the rank of Number 10 indicated that the deputy considered this category least important in the dispositional decisionmaking process.

\section{RESULTS OF THE PRE-TEST}

A pre-test was conducted to determine whether or not prescribed instructions were easily discernible. The researchers also needed to learn the average length of time necessary for an individual to complete the questionnaire. The amount of time required for each deputy to complete the questionnaire was the decisive factor in the size of the sample allotted to us by the Department of Public Safety. We also felt it crucial to investigate the possibility that section Two might influence a deputy's response to Section Three.

Four patrolmen who were neither in the sample nor on the panel participated in the pre-test. Two deputies were presented with the following format: 
Section One: personal and occupational characteristics

Section Two: general information categories

Section Three: contrived cases with attendant questions

The other two deputies were presented with the following format:

Section One: personal and occupational characteristics

Section Two: cases with attendant questions

Section Three: general information categories

The deputies stated that they had no problems understanding the prescribed instructions. The average length of time necessary to complete the questionnaire was forty minutes. The two deputies who had been given the second format complained that the contrived cases influenced their decisions pertaining to the rating of general information categories in Section Three. On the basis of their comments, the final format, which is the aforementioned second format, was selected as the Study Questionnaire. (See Appendix 1.) Page one of the questionnaire contains a general introduction to the study and the instructions for completing the questionnaire. Section one is composed of the questions regarding personal and occupational characteristics. Section Two requests that the deputies rank from 1 to 10 , in order of their importance, the information categories selected by the panel. Section Three contains contrived cases and attendant questions regarding dispositions of the subject involved in the case, rating the information categories in the case, the selected three categories which significantly influenced their decisions and a confidence scale.

\section{COLLECTION OF THE STUDY DATA}

To control situational variables, the questionnaire was to be administered to all deputies within a twenty-four-hour period, Work schedules of the population were checked by sergeants assigned to District 
Patrol Section and Youth Services Section. A special order, signed by Commanding officer of Operations Division, was sent to District Patrol Section and Youth Services Section. The order contained the names of the testees and the hour each testee was to report to the research assistant to complete the questionnaire. The researchers were present during all test periods.

Tests were administered during the hours when deputies, on all three shifts, were either reporting for or returning from patrol duties. This method of administration served two purposes. First, the deputy was not required to come to Operations Division Headquarters or Youth Services Section solely for the purpose of participating in the research project. Though deputies were paid overtime rate for taking part in the study, they could have resented the necessity of returning to Headquarters on their off-duty hours. Resentment could have caused some resistance to the study, and resistance could have affected the manner in which they responded to the questions contained in the questionnaire. Researchers believed that in using this method of administering the questionnaire they enhanced the validity of the deputy's responses. Second, using this method allowed for group testing rather than individual testing. When individuals take the same test at different times there is a chance that they will pass test contents along to other persons. When information regarding study material is passed on, the study is contaminated. Researchers believed that administering the questionnaire to three groups of patrolmen who were isolated from one another during the twenty-four period enhanced control over the extraneous variable "history." 
The research assistant explained the procedures of the questionnaire to the deputies once they were assembled. Deputies were asked not to put their name or address on any portion of the testing device. The deputies were advised that the research assistant was there to answer any questions they might have regarding the method in which to answer questions.

\section{TABULATION AND STATISTICAL ANALYSIS}

Upon completion of each test period, the questionnaires were collected by the researchers. The data was hand-tabulated on a master sheet which designated the responses to all questions for each deputy.

The research hypotheses were tested by conducting various statistical tests. Chi Square at .05 confidence level was chosen to determine whether relationships between the dependent and independent variables were empirically valid or due to chance. Initially, researchers intended to apply only Chi Square to the data. However, the number of observed frequencies in many cells proved to be less than five. Therefore, Chi Square could not be applied to all of the data.

The Mann-Whitney $U$ test for significance at the .05 confidence level was used to test for significant differences between the ranking of general information categories in Section One and the ranking of information categories in the three contrived cases presented.

Agreement indices were utilized to show the degree of accord between the general importance of information categories and the information categories selected as important in the simulated cases.

Tables were established to indicate the number of times a variable appeared in the devised distribution tables.

Descriptive findings and the results of statistical tests appear in the next chapter. 


\section{NOTES}

${ }^{1}$ Dennis C. Sullivan and Larry J. Siegel, "How Police Use Information to Make Decisions, An Application of Decision Games," Crime and Delinquency, Vol. 18, No. 3, July 1972.

${ }^{2}$ Oregon Revised Statutes, 164.345.

${ }^{3}$ Oregon Revised Statutes, 164.354.

${ }^{4}$ Oregon Revised Statutes, 164.365 .

${ }^{5}$ Phil Garrow, Pete Lautz, Tim Schechtel (coordinators Metropolitan Youth Commission), Youth Faces The Law, 1972. 
CHAPTER FOUR

\section{ANALYSIS OF THE DATA}

As explained in Chapter One the purpose of this study is to investigate systematically 1) the types of information categories which deputies believe play the most significant part in the decision-making process in general, 2) the types of information that deputies use when determining which dispositions to apply toward a juvenile charged with a particular offense, 3) the personal and occupational characteristics of the individual deputy which may have a bearing on the dispositions he applies towards a juvenile, and 4) the relationship among types of information deputies believe are important in particular cases, the dispositions they apply toward the juvenile, and the nature of the case presented.

The hypotheses will be presented and the data bearing upon each hypothesis will be discussed. Tests used to produce study results were Mann-Whitney U Test of significance at .05 confidence level, Two-Way Frequency Tables, Agreement Indices and Chi Square Test at the .05 level of confidence. Significant data not subjected to statistical tests will be presented in descriptive form.

A total of forty questionnaires was obtained from the study population. However, some deputies failed to answer all of the questions contained in the questionnaire. The data reflects only the number of answered questions in each particular area under consideration. The various values of $\mathrm{N}$ for each area are presented in each table. 
The first concern of this study was to determine if there is a difference in importance of the information categories used in making decisions.

Hypothesis I: There is no significant difference between information categories with respect to their general importance.

In order to determine if a difference existed among categories, those categories which deputies ranked among the first ten in general importance were given a score. Categories which deputies ranked as Number 1 received ten (10) points; categories ranked second received nine (9) points, and so on. The raw scores for each category were then ranked, indicating the relative importance of the categories to each other. Table 1 gives the raw scores and their ranking.

From an examination of Table 1 we rejected Hypothesis $I$. Plausible Alternate Hypothesis: There is a significant difference between information categories with respect to their general importance.

The raw scores for information categories were distributed over a wide range. The first five categories--offense, attitude of suspect, previous record, attitude of parent, mental health of suspect--have an aggregate score which is almost twice that of the remaining thirteen categories. This is an obvious indication of the general importance of these five categories over the other thirteen. The categories of age, concealed weapon, victim involved and peer associations followed the first five categories in importance. The raw score for each of these categories was significantly high so that we might assume that these categories 
TABLE 1

RANKING OF INFORMATION CATEGORIES ACCORDING TO IMPORTANCE

\begin{tabular}{|c|c|c|c|}
\hline Rank & $\begin{array}{l}\text { Order of Categories } \\
\text { in Questionnaire }\end{array}$ & $\begin{array}{l}\text { Rank of Categories } \\
\text { According to Importance }\end{array}$ & $\begin{array}{l}\text { Raw } \\
\text { Score }\end{array}$ \\
\hline 1 & offense & offense & 367 \\
\hline 2 & attitude of suspect & attitude of suspect & 316 \\
\hline 3 & age & previous record & 264 \\
\hline 4 & $\operatorname{sex}$ & attitude of parent & 228 \\
\hline 5 & time during shift & mental health/suspect & 215 \\
\hline 6 & shift & age & 185 \\
\hline 7 & location of offense & concealed weapon & 159 \\
\hline 8 & attitude of parent & victim involved & 121 \\
\hline 9 & appearance & peer associations & 95 \\
\hline 10 & mood of officer & sex & 44 \\
\hline 11 & previous record & number of suspects & 43 \\
\hline 12 & victim involved & shift & 38 \\
\hline 13 & onlookers present & local resident & 26 \\
\hline 14 & peer associations & location of offense & 23 \\
\hline 15 & number of suspects & mood of officer & 21 \\
\hline 16 & local resident & time during shift & 19 \\
\hline 17 & concealed weapon & appearance & 19 \\
\hline 18 & mental health/suspect & onlookers present & 16 \\
\hline
\end{tabular}

continued to be of some general importance. The remaining nine categories-sex, number of suspects, shift, local resident, location of offense, mood of officer, time during shift, appearance, onlookers present--have such low 
raw scores that we might assume that these are relatively unimportant, in general.

The findings in Table 1 correspond closely with the results of the Sullivan Siegel study. 1 Sullivan and Siegel found that officers use five pieces of information before they make a decision regarding disposition of a juvenile. In the Sullivan Siegel study the five pieces of information most crucial to decision-making were offense, age, previous record, attitude of offender and family relationship.

Results of the study presented in this paper indicate that deputies of the Department of Public Safety also consider offense, previous record, attitude of suspect and family relationship (attitude of parent) among the five most important information categories in the decision-making process. Mental health was considered more important than age by the deputies in this present study.

In contrast, however, mental health was not listed as one of the information categories to be considered in the Sullivan Siegel study. This in itself is significant. It indicates that the deputies of the Department of Public Safety consider mental health an important factor in the decision-making process.

Hypothesis II: There is no significant difference between the ranking of general information categories and the ranking of information categories in particular cases.

To investigate if there is a difference between the ranking of general information categories and the ranking of information categories in particular cases, a Mann-Whitney U Test for significance at the .05 level of confidence was used. 
Raw scores and rankings displayed in Table 1 were utilized as Sample One. Sample Two consisted of the raw scores and rankings of the three categories considered important to disposition in Cases 1, 2, and 3. Scores were determined by the categories' importance. If a category was deemed most important to disposition it received a score of three, if it was deemed second in importance it was given a score of two, if it was deemed least important it was given a score of one. The scores for each category in all three cases were computed and then the category was ranked according to the total score achieved.

TABLE 2

RANKING OF INFORMATION CATEGORIES IN GENERAL AS COMPARED TO RANKING OF CATEGORIES

IN CASES PRESENTED

$\begin{array}{r}U=4 \\ \text { The critical of } U=109 \\ \hline\end{array}$

The results of Table 2 significantly show that we rejected Hypothesis II.

Plausible Alternate Hypothesis: There is a significant difference between the ranking of general information categories and the ranking of information categories in particular cases.

Information categories--offense, attitude of suspect, previous record, attitude of parent, and mental health of suspect--remained in first through the fifth rank orders in both samples. However, the position of each category varied between Sample One and Sample Two. 
The significant differences in the ranking of information categories between the two sample occurred below the rank of 5 . The ranking of categories 6 through 18 in Sample One was significantly different than the ranking of these categories in Sample Two.

We conclude that there was agreement between what deputies generally believed were the five most important information categories and the five information categories they actually applied to specific cases. Beyond the first five categories deputies disagreed significantly with the relative importance of the remaining thirteen categories. Hypothesis III: There is no agreement between the information categories which are professed to be used by the deputies and the information categories which are actually used by the deputies in the cases presented.

To further explore whether or not consistency existed between the ten categories generally professed to be important and the categories which were actually utilized by the deputies in the three cases, the researchers constructed an agreement index.

The table was constructed in the following manner. In Section II, deputies were asked to rank from 1 to 10 the information categories that they believed were most important in regards to dispositions of cases in general. In Part $C$ of each case in Section III, deputies were requested to list the three most important information categories used in reaching their disposition of that case. The data from Section II and Section III, Part $C$, for each deputy in the sample was recorded on a master sheet. From the master sheet a comparison was made for each deputy between his responses to Section II and his responses to Part C of Section III for each 
case. If all three (3) of the information categories in Part C of Section III for each case were included among the ten (10) categories listed by the individual deputy in Section II, then a score of three (3) was given to the deputy. If only two were included, a score of two was given. If only one was included, a score of one was given. This procedure was repeated for each case and for each deputy. The individual scores for Cases I, II, and III were totalled separately and a mean for each case was established.

TABLE 3

AGREEMENT BETWEEN PHILOSOPHY AND PRACTICAL APPLICATION

\begin{tabular}{lccc}
\hline & Case I & Case II & Case III \\
$\mathrm{N}$ & 40 & 38 & 38 \\
$\overline{\mathrm{X}}$ & 2.825 & 2.684 & 2.736 \\
$\mathrm{I}^{*}$ & 94.2 & 89.5 & 91.2 \\
\hline * & &
\end{tabular}

If the mean agreement for any case was 3.0 this would indicate total agreement between the important categories in the cases presented and the ten listed important categories in general. The findings in Table 3 do not indicate total agreement existed between cases presented in this study and the ten 1 isted important categories in general. However, the means on Table 3 indicate that there was significant agreement between what deputies generally professed to be the ten most important information categories and the categories they selected in making a decision regarding a juvenile disposition in the cases presented. Therefore, we rejected Hypothesis III. 
Plausible Alternative Hypothesis: There is considerable agreement between the information categories which are professed to be used by the deputies and the information which is actually used by the deputies in the cases presented.

The mean values in Table 3 indicate the marked influence that categories offense, attitude of suspect, previous record, attitude of parent, mental health of suspect, age, concealed weapon, victim involved, peer association and sex have upon the decision-making process with respect to juvenile dispositions.

Since agreement means in Table 3 were so close to 3.0 (total agreement), researchers decided to investigate the extent of agreement that existed among the five most important categories in general and the three categories selected as important in the cases presented.

TABLE 4

AGREEMENT BETWEEN IMPORTANT CATEGORIES IN CASES COMPARED WITH THE FIVE LISTED IMPORTANT CATEGORIES IN GENERAL

\begin{tabular}{cccc} 
& Case I & Case II & Case III \\
& $\mathrm{N}=40$ & $\mathrm{~N}=38$ & $\mathrm{~N}=38$ \\
$\overline{\mathrm{X}}$ & 2.425 & 2.105 & 2.236 \\
$\mathrm{I}^{*}$ & 80.8 & 70.1 & 74.5 \\
\hline
\end{tabular}

* Per cent of maximum agreement

The results of Table 4 show that the mean agreement between the selected five most important categories in general and the three categories selected as important in cases presented was still relatively 
close to total mean agreement of 3.0. These findings are further indications of the consistency which existed between what the deputy philosophically believed were the important types of information in the decision-making process and the types of information that the deputy utilized in the cases presented.

In analyzing the findings in Table 3 we conclude that the study population has learned the importance of these categories. The learning process has included their period of formal education prior to entrance into the department, their extended period of police training and their period of on-the-job training as recruits. Actual experience may have reinforced their belief in the importance of these categories. We can further speculate that the sum total of these experiences has instilled a high level of confidence in the reliability of these kinds of information for reaching appropriate decisions in the dispositions of juveniles.

Hypothesis IV: There is no difference in importance of categories offense, attitude of suspect, attitude of parent, mental health of suspect and previous record, as compared to chance in the cases presented.

Previous data indicate that categories offense, mental health of suspect, attitude of parent, attitude of suspect and previous record are the five most important information variables. However, researchers were interested in investigating whether or not these categories varied in their importance among the cases presented. To determine the existence or nonexistence of variation, tables were constructed by researchers for each case. These tables reveal the number of times each 
category was selected as one of three categories which influenced the disposition of the case under consideration.

Table 5 shows that the deputies relied upon these categories when making a decision, but they did not believe that the importance of each category was constant from case to case. The importance of these categories varied among cases. Therefore, we rejected Hypothesis IV. Plausible Alternate Hypothesis: There is a difference in the

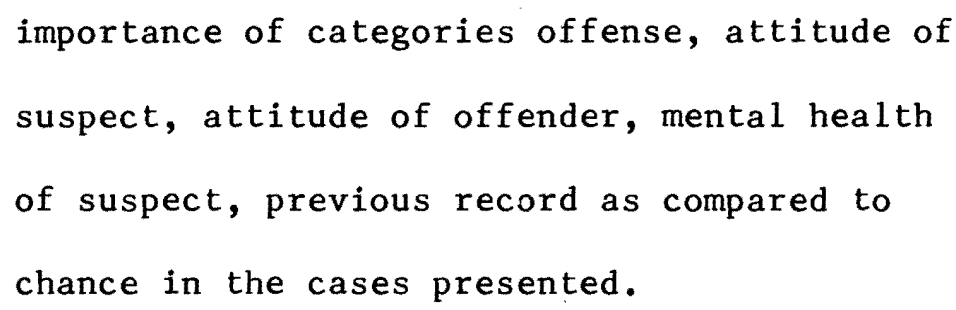

The findings in Table 5 show that deputies in the sample are sensitive to the mental health of the suspect. In Cases 2 and 3 , the mental health of the juvenile was suspect. The category mental health of suspect was considered very important with respect to disposition in these cases. The fact that these deputies selected this category as important corresponds with the findings of Hollingshead and Redlich. They state:

Policemen, of all community officials, are most likely to perceive that a psychotic individual is disturbed or in need of psychiatric care. . . Usually when the police arrest a disturbed individual, they perceive the nature of his difficulty before his family does. . . . Police are Very Important Persons in the process of "diagnosing" severely disturbed and antisocial behavior. . . 2

The findings in Table 5 also contradict the generally believed proposition that once a police officer knows about the offense committed, he makes a decision to take the offender into custody. Deputies utilize information categories other than offense when they are required to make 
TABLE 5

NUMBER AND PER CENT JUDGING CATEGORIES

TO BE AMONG TOP THREE IN IMPORTANCE

\begin{tabular}{|c|c|c|c|c|c|c|}
\hline \multirow[b]{2}{*}{ Category } & \multicolumn{2}{|c|}{ CASE $1 \mathrm{~N}=39$} & \multicolumn{2}{|c|}{ CASE $2 \mathrm{~N}=37$} & \multicolumn{2}{|c|}{ CASE $3 \mathrm{~N}=38$} \\
\hline & Number & $\begin{array}{l}\text { Per Cent } \\
\text { of } N \\
\end{array}$ & Number & $\begin{array}{l}\text { Per Cent } \\
\text { of } \mathrm{N} \\
\end{array}$ & Number & $\begin{array}{l}\text { Per Cent } \\
\text { of } \mathrm{N} \\
\end{array}$ \\
\hline Offense & 33 & .84 & 10 & .27 & 16 & .42 \\
\hline Attitude of suspect & 29 & .74 & 18 & .48 & 25 & .65 \\
\hline Age & 2 & .05 & 4 & .10 & 1 & .02 \\
\hline Sex & 1 & .02 & 0 & 0 & 0 & 0 \\
\hline Time during shift & 0 & 0 & 0 & 0 & 0 & 0 \\
\hline Shift & 0 & 0 & 1 & .02 & 0 & 0 \\
\hline Location of offense & 3 & .07 & 0 & 0 & 1 & .02 \\
\hline Attitude of parent & 26 & .66 & 28 & .75 & 22 & .57 \\
\hline Appearance & 1 & .02 & 6 & .16 & 3 & .07 \\
\hline Mood of officer & 1 & .02 & 2 & .05 & 3 & .07 \\
\hline Previous record & 6 & .15 & 10 & .27 & 10 & .26 \\
\hline Victim involved & 2 & .05 & 0 & 0 & 2 & .05 \\
\hline Onlookers present & 0 & 0 & 0 & 0 & 1 & .02 \\
\hline Peer associations & 0 & 0 & 3 & .08 & 0 & 0 \\
\hline Number of suspects & 0 & 0 & 0 & 0 & 2 & .05 \\
\hline Local resident & 6 & .15 & 3 & .08 & 0 & 0 \\
\hline Concealed weapon & 5 & .12 & 1 & .02 & 1 & .02 \\
\hline $\begin{array}{l}\text { Mental health of } \\
\text { suspect }\end{array}$ & 5 & .12 & 29 & .78 & 26 & .68 \\
\hline
\end{tabular}


a decision regarding dispositions. Offense was considered the most important category in only one case presented. The accumulated totals from Table 5 show that the categories of attitude of parent, attitude of suspect and mental health were more important among cases than were the categories offense and previous record.

After investigating the types of information categories that deputies utilized the researchers' next concern was to investigate the dispositions that deputies made.

In reviewing the dispositions arrived at by the deputies in this study, it is necessary for the reader to be aware that in the geographic area served by the Department of Public Safety there are very few facilities which provide assistance to juveniles. This fact poses a dilemma for the deputies. Deputies have stated that in many cases they believe that a juvenile should be removed from the home, but the question of where to take him other than the Court is a real problem.

At the time that this study was conducted, agencies, other than the Court, which provided twenty-four-hour services to juveniles were almost nonexistent. The only recourse a deputy has after five P.M. or on weekends when he decides to take a juvenile into custody is the Juvenile Court.

Many deputies have expressed their reluctance to take this action. They know from experience that the majority of juveniles who come in contact with the Court are detained only until a Court hearing is held. The juvenile is then released and returns to his home. The Court does provide counseling for the juvenile and his family, and at least this is better than nothing at all. 
Also, some deputies are hesitant to take a youth to Juvenile Court because they believe that once a youth has been exposed to this experience the impact of future exposures to the Court and detention diminishes greatly. For some, the experience even affords status among juvenile peers.

It would be interesting to see if there would be a change in dispositions selected if facilities for the treatment and rehabilitation of juveniles were expanded.

Hypothesis V: There is no significant difference among officers as compared to chance with respect to dispositions in the three cases presented.

Currently, deputies who are employed by the Department of Public Safety, Multnomah County, Oregon, have seven dispositional options available when dealing with a juvenile offender. These options are:

1. Warn and release at the scene.

2. Release to parents without writing a custody report.

3. Write a custody report and release juvenile on the scene with follow-up notification to parents.

4. Write a custody report and release juveniles to parents at home.

5. Write a custody report and release juvenile to parents at operations Division Headquarters.

6. Take into physical custody and transport to a counseling agency of the Court.

7. Take into physical custody and transport to Juvenile Court. In order to investigate those dispositions which deputies utilized in the cases presented, and in order to investigate if there is a 
significant difference among officers with respect to disposition in the three cases presented, Table 6 was constructed.

TABLE 6

VARIOUS DISPOSITIONS BY CASES

CASE $1 \quad \mathrm{~N}=39$

Disposition

$\begin{array}{lrrrrrrrr} & 1 & \underline{2} & \underline{3} & \underline{4} & \underline{5} & \underline{6} & \underline{7} & \text { Total } \\ \text { Number } & 3 & 1 & 2 & 9 & 8 & 0 & 16 & 39 \\ \text { Per cent } & .08 & .03 & .04 & .23 & .21 & 0 & .41 & 100\end{array}$

CASE $2 \quad \mathrm{~N}=37$

Disposition

$\begin{array}{llllllllr} & 1 & \underline{2} & \underline{3} & \underline{4} & \underline{5} & \underline{7} & -1 & \text { Total } \\ \text { Number } & 2 & 1 & 4 & 13 & 0 & 10 & 7 & 37\end{array}$

$\begin{array}{lllllllll}\text { Per cent } & .05 & .03 & .10 & .36 & 0 & .27 & .19 & 100\end{array}$

CASE $3 \quad \mathrm{~N}=38$

Disposition

\begin{tabular}{lcccccccr} 
& 1 & $\underline{2}$ & $\underline{3}$ & $\underline{4}$ & $\underline{5}$ & $\underline{6}$ & $\underline{7}$ & Total \\
Number & 0 & 0 & 8 & 9 & 0 & 8 & 13 & 38 \\
Per cent & 0 & 0 & .21 & .24 & 0 & .21 & .34 & 100 \\
\hline
\end{tabular}

Table 6 indicates that dispositions are not equally divided among the options in the cases presented. There is a variation in each case and among cases with respect to the disposition applied. Therefore, we rejected Hypothesis $\mathrm{V}$. 
Plausible Alternate Hypothesis: There is a difference among deputies as compared to chance with respect 10 disposition applied.

In examining the data in Table 6 , the percentage of the sample who preferred to take the juvenile into custody was slightly higher than those who preferred to write a custody report and release the juvenile to his parents. The number of deputies who just warned and released the juvenile was very small by comparison.

These findings confirm the results of Wilson's comparative study between a nonprofessional and a professional police agency. ${ }^{3}$ Wilson found that a youth was one and a half times more likely to be referred to Court when he had contact with a police officer working for a professional agency than a youth who had contact with a police officer working for a nonprofessional police department. However, Wilson believed that more officers working for professional police departments refer juveniles because they are interested in seeing that the youth receives some rehabilitation and treatment. They do not refer because they are more punitive in their approach towards juveniles than are officers working for a nonprofessional department.

Since dispositions in the cases presented were closely divided between those deputies who took the youth into custody and those deputies who wrote a custody report and released the youth, the researchers determined to investigate if personal and occupational characteristics of the deputy may have contributed to these decisions.

Hypothesis VI: There is no significant relationship between age of deputy and the disposition applicd. 
Hypothesis VII: There is no significant relationship between number of years in police work and the disposition applied.

Hypothesis VIII: There is no significant relationship between married and single deputies and disposition applied .

Hypothesis IX: There is no significant relationship between deputies who have children and deputies who do not have children and the disposition applied.

Initially, it was the intention of the researchers to include education as a variable. The data revealed, however, that thirty-five of the deputies in the sample have obtained a bachelor's degree and the remaining five deputies have completed one or more years of college. Consequently, the variable of amount of education was considered to be constant and was not included.

Dispositions were divided into two categories: 1 . take juvenile into custody; and 2 . release juvenile.

Personal and occupational characteristics were divided according to determined median of each characteristic under consideration. The cutting points for each characteristic are:

1. The category of years in police work reflects the dispositional decisions of deputies who have mor or less than four years in police work.

2. The age category reflects the dispositional decision of those deputies who are below 28 years of age as opposed to those who are 28 years of age and older. 
3. The children category reflects the dispositional decisions of those deputies who have one or more as opposed to those deputies who do not have children.

4. The category of marital status reflects the dispositional decisions of those deputies who are married as opposed to those deputies who are single. One deputy in the sample was divorced. His responses were included in the single deputy category.

To investigate if there was a significant relationship between personal and occupational characteristics and dispositions, A Chi Square Test for significance at the .05 confidence level was used.

Table 7 indicates that there was no significant relationship between personal and occupational characteristics and disposition applied. Therefore, Hypotheses VI, VII, VIII, IX were accepted.

Hypothesis X: There is no relationship between shift worked and disposition applied.

The occupational category, shift, could not be tested by a Chi Square. Theoretical frequencies were too often below the value of five even with combined categories. Therefore, to investigate if the shift a depuly works has an impact on dispositions, a table was constructed.

Table 8 shows a highly random distribution of dispositions among the shifts. Therefore, Hypothesis $X$ was accepted.

In the cases presented, the first shift was slightly more inclined to take juveniles into custody than were other shifts. The first shift tended to be more in accord with regard to disposition of juveniles than were the other two shifts. There was little difference among shifts in the tendency not to use dispositions 1 and 2, and with Case I, not to use disposition Number six. 
TABLE 7

CATEGORIES OF PERSONAL CHARACTERISTICS AS THEY RELATE

TO JUVENILE DISPOSITIONS. $\mathrm{N}=39$

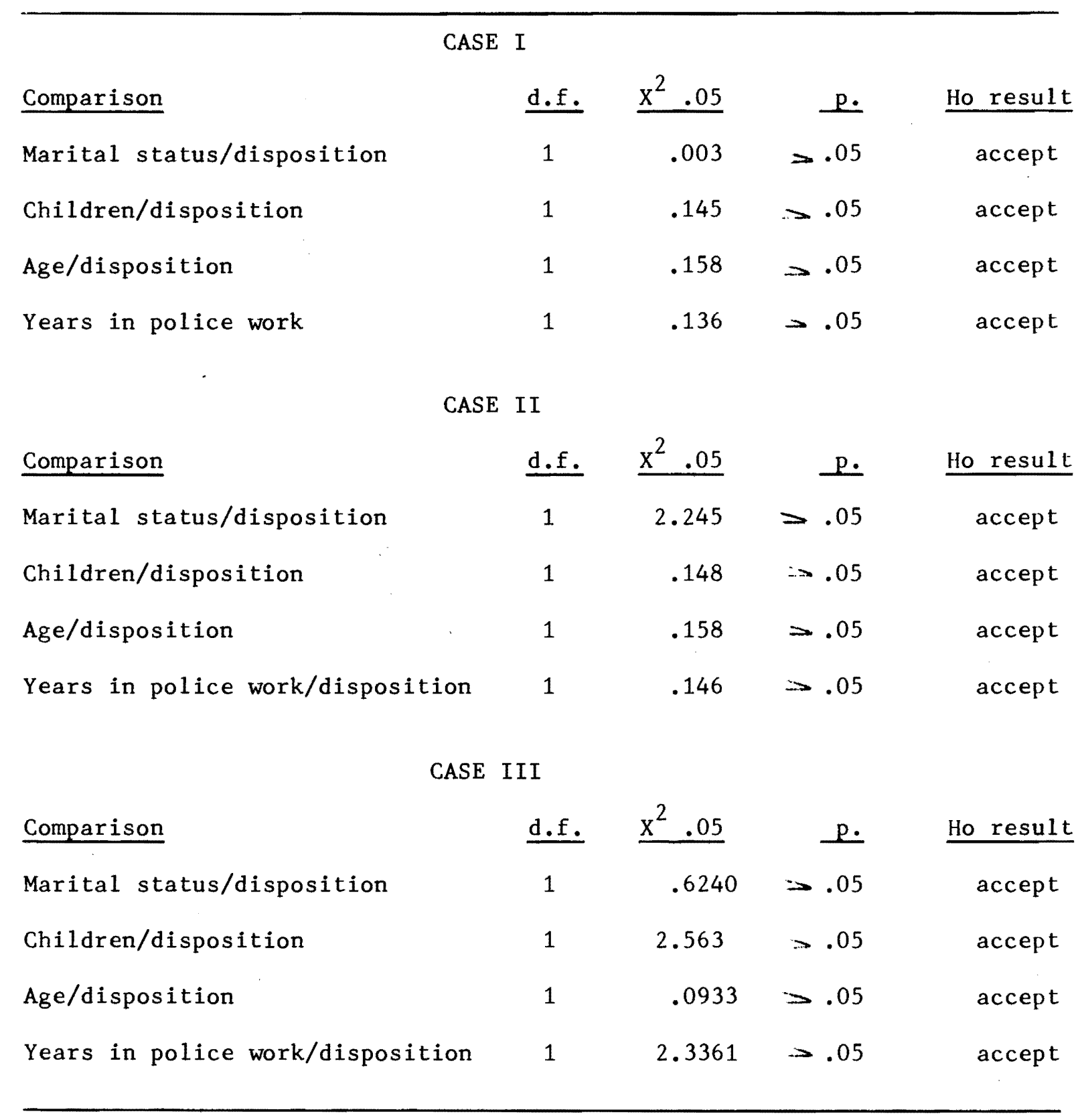


TABLE 8

NUMBER AND PER CENT CHOOSING VARIOUS DISPOSITIONS

IN THE THREE CASES, BY SHIFTS

\begin{tabular}{|c|c|c|c|c|c|c|c|c|}
\hline \multicolumn{9}{|c|}{$\begin{array}{l}\text { FIRST SHIFT } N=16 \\
\text { Disposition }\end{array}$} \\
\hline & 1 & 2 & 3 & 4 & 5 & 6 & 7 & Total \\
\hline Case I & 1 & 0 & 1 & 2 & 3 & 0 & 9 & 16 \\
\hline Per cent & .06 & 0 & .06 & .13 & .18 & 0 & .56 & 100 \\
\hline Case II & 1 & 1 & 0 & 8 & 0 & 4 & 1 & 15 \\
\hline Per cent & .07 & .07 & 0 & .53 & 0 & .27 & .07 & 100 \\
\hline Case III & 0 & 0 & 2 & 4 & 0 & 3 & 7 & 16 \\
\hline Per cent & 0 & 0 & .13 & .13 & 0 & .18 & .44 & 100 \\
\hline \multicolumn{9}{|c|}{$\begin{array}{l}\text { SECOND SHIFT } \mathrm{N}=8 \\
\text { Disposition }\end{array}$} \\
\hline Case I & 1 & 1 & 0 & 2 & 2 & 0 & 2 & 8 \\
\hline Per cent & .13 & .13 & 0 & .26 & .26 & 0 & .26 & 100 \\
\hline Case II & 0 & 0 & 2 & 2 & 0 & 2 & 2 & 8 \\
\hline Per cent & 0 & 0 & .26 & .26 & 0 & .26 & .26 & 100 \\
\hline Case III & 0 & 0 & 2 & 2 & 0 & 2 & 1 & 8 \\
\hline Per cent & 0 & 0 & .26 & .26 & 0 & .38 & .13 & 100 \\
\hline \multicolumn{9}{|c|}{$\begin{array}{c}\text { THIRD SHIFT } N=11 \\
\text { Disposition }\end{array}$} \\
\hline Case I & 1 & 0 & 1 & 4 & 2 & 0 & 2 & 11 \\
\hline Per cent & .09 & 0 & .09 & .36 & .18 & 0 & .27 & 100 \\
\hline Case II & 1 & 0 & 1 & 2 & 0 & 3 & 3 & 10 \\
\hline Per cent & .10 & 0 & .10 & .20 & 0 & .30 & .30 & 100 \\
\hline Case III & 0 & 0 & 1 & 3 & 0 & 2 & 4 & 10 \\
\hline Per cent & 0 & 0 & .10 & .30 & 0 & .20 & .40 & 100 \\
\hline
\end{tabular}


Analysis of the data reveals that deputies do make different decisions regarding dispositions, but these differences in the selection cannot be attributed to these personal or occupational traits. We conclude, on other grounds, that the professional nature of the Department of Public Safety excludes these characteristics from having an impact on dispositions.

The findings tend to show that the dispositions on juveniles in the cases presented were based on the judgment of the individual deputy, but that the judgment was not biased by personal or occupational variables. Table 8 also reveals considerable differences among deputies with respect to dispositions applied.

The next focus of interest was in determining if a relationship existed among: 1) The types of information that the deputies perceived as important in the case; 2) The deputies' disposition of that case; and 3) The nature of the case. No statistical test was designed for this purpose because of the complexity of interrelationships. Researchers determined that this portion of the study would be confined to a descriptive analysis of the nature of the case and data contained in Tables 5 and 6 .

In analyzing the types of information deputies selected as important to case disposition, only those information categories in Table 5 which were selected ten or more times will be reported in the descriptive analysis.

Dispositions are divided into three sections: 1) Warn and release (dispositions one and two listed above); 2) Write a custody report and release juvenile (dispositions three, four and five 1isted above); and 3) Take into physical custody (dispositions six and seven listed above). 
Case I

The offense in this case was serious. The juvenile threw a rock at a moving vehicle. The rock shattered the windshield of the car and could have caused physical injury to the victim. The attilude of the suspect was negative; he tried to elude the deputy; he was surly in his responses to the deputy's questions; he initially denied being involved in the incident. The attitude of the parents was positive; they were concerned with the boy's behavior and they stated that appropriate action would be taken. They were anxious to know if anyone was injured; they offered to make restitution for damages. The juvenile had no previous record.

Table 6 shows that 48 per cent of the deputies elected to write a custody report and release the juvenile. Forty-one per cent of the deputies elected to take the juvenile into custody. Only 11 per cent chose simply to warn and release the juvenile.

In Case I only three categories were listed ten or more times in Table 5. These categories were offense, attitude of suspect and attitude of parent.

Researchers conclude that the forty-one per cent of the deputies who took the juvenile into custody considered that the offense and the attitude of suspect were serious enough to warrant this action. The forty-eight per cent who released the juvenile believed that though the offense was serious the attitude of the parent eliminated the necessity of taking the juvenile into custody. Eleven per cent didn't view the case as being serious enough to take any action other than giving a warning to the boy. 
Further, we conclude that though the offense was listed as the most important information category, other factors such as attitude of suspect and the attitude of the parents were taken into consideration before disposition was decided upon by the deputies.

Case II

The offense in Case II was minor. Encouraged by his brothers, the suspect had pulled up some rose bushes which were in the neighbor's yard. The mental health of the suspect was doubtful; he was unable to respond to questions; he reacted to the situation by withdrawing; he expressed mixed and inappropriate emotions. The attitude of the parents was negative; they were openly hostile toward the deputy and toward the complainant; they were unconcerned with the offense; they were on the one hand defensive of the boy while on the other hand they were abusive toward him.

The attitude of the suspect showed a disregard for the offense committed. His disregard could be attributed to the questionable nature of his mental health. In this particular case, the researchers believe that both mental health and attitude of suspect are closely aligned. The juvenile had a previous record. He had been apprehended for curfew violations, vandalism, and fire setting.

Table 5 indicates that fifty-six per cent of the deputies elected to take the boy into custody. Forty-six per cent elected to write a custody report and release the juvenile to his parents. Eight per cent decided not to write a custody report; this portion of the deputies did not believe that any follow-up action was necessary in this case.

offense and previous record were considered by the deputies when they made their decisions in regard to disposition. However, Table 5 
shows that mental health of the suspect, attitude of the suspect and attitude of the parents were chosen as the most important criteria on which deputies based their decisions.

Since the offense was minor, we can conclude that deputies took the boy into custody, or requested that a follow-up investigation be conducted because they were aware that he needed assistance beyond that which his parents could provide.

Case III

In Case III, the offense was most serious of all of the cases presented. The girl had destroyed valuable school property worth over one thousand dollars. The mental health of the suspect was doubtful. She committed the offense because she had become angry and lost control over her actions. Her attitude was negative; she attempted to escape being apprehended by school officials; she was upset because she was caught, not because she had committed the offense. She had a previous record for shoplifting, possession of drugs, and runaway. Her parents reacted with despair and confusion. They admitted that they no longer could control the girl.

In Case III, fifty-five per cent of the deputies decided to take the girl into custody. Forty-five per cent elected to write a custody report and release the girl to her parents. No deputies decided to release her with only a warning.

Mental health of the suspect, attitude of the suspect, attitude of the parent, offense and previous record were the five categories which contributed most heavily to the disposition of the case. In this case all of these categories had negative implications. Therefore, we cannot conclude that any particular category or combination of categories 
contributed to the division of opinions with respect to disposition. In this study we can only conclude that this case is a good example of the use of individual discretion inherent in the decision-making process. It is an indication of how much latitude exists in the disposition of cases involving juveniles. Forty-five per cent of the deputies released the girl to her parents. Fifty-five per cent took her into custody. If dispositions matter, close to half of the deputies made less than optimum disposition.

In this chapter, for the most part, comments have been restricted to the major concerns of this study. Tables have been presented for those interested in exploring in detail the considerable number of interrelationships as related to special areas of interest.

The final chapter will be directed toward conclusions from the study. 


\section{NOTES}

${ }^{1}$ Dennis C. Sullivan and Larry J. Siegel, "How Police Use Information to Make Decisions, An Application of Decision Games," Crime and Delinquency, Vol. 18, No. 3, July, 1972. (Note: the Sullivan and Siegel. study provided writers of this paper with a conceptual framework for developing the methodology used in their study.)

${ }^{2}$ August B. Hollingshead and Frederick C. Redlich, Social Class and Menta1 Illness, John Wiley and Sons, Inc., New York, N. Y., 1958, p. 184.

3 James Q. Wilson, "The Police and the Delinquent in Two Cities" (unpublished manuscript), p. 25. 


\section{CHAPTER FIVE}

\section{CONCLUSIONS}

\section{Discussion}

The research for the preparation of this report has resulted in a number of conclusions about which a series of summary statements were made. These conclusions were drawn from a review of the literature as well as from the findings which were determined from the data utilized.

1. Much of the literature on the use of discretion is primarily concerned with the decision-making process at the adjudicatory and postadjudicatory stages of the criminal and juvenile justice system. Few studies have concentrated on the decision-making of police officers at the pre-adjudicatory stage of the criminal and juvenile justice system. Yet, it is the decisions which are made by police officers, as agents of the legal system, that determine whether or not an individual will become subject to court processes.

2. Studies reveal that the focus of attention in the decisionmaking process with respect to juveniles has been upon the characteristics, experiences and a variety of attributes of young people who have been labeled delinquent. Few studies have concentrated upon the individual and collective characteristics of the police officer who makes the decision as to whether or not the youth will be referred to the court and be subsequently subject to labeling. Also, few studies have 
focused upon the types of information that police utilize when making a dispositional decision with respect to juveniles.

3. Deputies holding positions with the District Patrol Section and Youth Services Section of the Department of Public Safety, Multnomah County, Oregon, selected eighteen types of information which they generally associated with the decision-making process. The eighteen types of information were: offense, attitude of suspect, age, sex, mood of deputy, attitude of parent, time during shift, shift, location of offense, local resident, peer association, concealed weapon, previous record, mental health of suspect, victim involved, onlookers present, number of suspects, and appearance.

The deputies' ability to cite a delimited number of types of information which they believed were generally associated with the decisionmaking process indicated that the deputies were aware that a certain set of criteria does come into play when the police officer makes a decision with respect to a juvenile.

Although eighteen information categories were selected as generally used by deputies when making a decision involving a juvenile, deputies primarily used five pieces of information (offense, mental health of suspect, attitude of offender, attitude of parent, and previous record; when making a dispositional decision on a juvenile. (The use of five pieces of information supports the findings of the Sullivan and Siegel study. ${ }^{1}$ )

Deputies supported the importance of the five information categories listed above. They were ranked in one of the first five positions with respect to their general importance by the majority of the deputies. In the contrived cases presented in this study these five types of information were selected as having the most influence upon dispositional 
decisions. This indicated that with respect to these five types of information there was agreement between what deputies believed were generally the important types of information used in the decision-making process and the types of information they actually used for decisionmaking in the contrived cases presented.

Deputies did not support the relative importance of the remaining thirteen types of information. There was no significant agreement between the general ranking of these information categories and the ranking of these information categories as they were applied to the contrived cases in this study.

4. Deputies of the District Patrol Section and the Youth Services Section are concerned with treatment and rehabilitation of juvenile offenders whose behavior indicated the need for specialized attention. Because of this philosophy a set of criteria which went beyond the nature of the offense was taken into consideration when the deputies applied a disposition toward the juvenile in the contrived cases presented. The characteristics of the individual youth, his attitude, his mental health, attitude of his parents, his previous record, had as much if not more influence on the deputy's dispositional decision as did the offense committed.

5 Only a small percentage of the deputies warned and released the juveniles who were the principals in the contrived cases. The majority of the deputies elected either to release the juvenile to his parents after writing a custody report (which requires a follow-up investigation) or take the youth into custody and transport him to an agency of the court. These decisions were related to the professional nature of the 
Department and to the deputies' concern that the youth receive rehabilitation rather than punishment. These findings are supported by James Q. Wilson, ${ }^{2}$ and through participant observation.

Considerable discretion was exercised by the deputy when making a dispositional decision on a juvenile offender. These findings support the study of Wayne R. LaFave. ${ }^{3}$ The disposition of a case was dependent upon the decision of the individual deputy investigating the case. Much latitude was evidenced in the dispositions which were applied in each case. If dispositions matter, deputies need to discuss the nature of dispositions to gain a consensus regarding which disposition should apply under various sets of circumstances. At present, both the public and the juvenile offender appear justified in their opinions that dispositions are arbitrary judgments by police officers.

6. Personal and occupational characteristics studied had no significant impact on a deputy's dispositional decision. This could be attributed to the academic background of the deputy, the on-the-job training he received and factors of perception not analyzed in this study.

7. The majority of deputies were sensitive to the differences of circumstances in each contrived case. Although the majority of deputies agreed on the important information categories present within each case, they disagreed on which disposition to apply to each case. This is evidence that more attention needs to be given to why deputies make the dispositions they do.

The salient points are: that the deputies utilized, primarily, five types of information when making a dispositional decision; that the nature of the case and the characteristics of the juvenile had as much influence 
on which disposition was applied as did the offense committed; that selective discretion with respect to dispositions was widely used; that there was little consensus among deputies as to which disposition should be applied to a particular case; and that the personal and occupational characteristics of the deputies had no significant impact on their decision-making with respect to the contrived cases presented.

\section{$\underline{\text { Recommendations }}$}

First, it is recommended that further research studies be implemented within the Department of Public Safety to determine: 1) which dispositions are better than others; 2) whether or not the deputies' attitudes toward the Juvenile Court influenced their individual decisions; 3) whether there is a relationship between factors of perception and factors of disposition; 4) whether the decision process as it stands is faulty; 5) whether additional dispositions are necessary. Data collected from this study and from the suggested studies should be carefully analyzed and from this analysis formal guidelines should be constructed for decision-making with respect to juveniles. The existing approach to decision-making is vague, offering neither assistance to the deputy nor consistency and predictability for the juvenile.

It is recommended that comparative studies be conducted to test for differences which might exist between deputies working for a "professional" organization and deputies working for a "fraternal" organization, focusing on types of information the deputies believe are significant to decisionmaking. This kind of comparative study could yield data on the variations of decision-making in juvenile cases. 
It is recommended that a comparative study be conducted between deputies and social workers who work with juveniles. This study could focus on the information generally considered by the deputies to be important to decision-making. Do social workers see this information as important for decision-making? What types of information do social workers agree are important (unimportant)?

The second recommendation is that information regarding the circumstances encountered by the deputy at the scene of contact with juveniles should be passed on by the reporting deputy to the court intake person. The deputy should provide as much written and verbal information as possible regarding his reasons for referring the juvenile to court. It is often the case that the intake worker is without important information with respect to what occurred at the scene. Facts pertaining to the attitude of the offender, attitude of parent, peer association and mental health of the suspect are often not conveyed to the intake person. The worker interviews the juvenile after the crisis is over and the juvenile's defenses are again intact. This makes the intake person's efforts at getting accurate information about the juvenile and his situation more difficult. Therefore, the intake person's decision on what appropriate action to take is affected.

\section{Limitations of the Study}

This study may be criticized because the sample was taken from only one organization, the Department of Public Safety, Multnomah County, Oregon. The deputies in the sample were all college educated, and had received extensive training in police work prior to becoming regular duty officers. The organization maintains high professional standards and 
promotes a courteous approach to police work. Therefore, it would be difficult to generalize from this study to other counties. Nevertheless, the data collected should contribute to the limited amount of empirical research on the types of information and related dispositions law enforcement officers utilize when making a decision with respect to a juvenile. Another limitation of the study was the use of a self-reporting questionnaire. Such a testing device cannot prevent respondents from "faking" answers. Many times there is a high probability of answering statements which are positively correlated with social desirability of a particular item in question. Preiss and Ehrlich ${ }^{4}$ comment on selfreporting instruments by saying that "there is always the potential for inconsistency between a person's reported answers to questions and his actual behavior." Furthermore, it is believed that persons who have obtained a higher educational level are more likely to be "test wise." Hopefully, false answers were kept to a minimum because respondents answered the questions in a nonthreatening situation and they did not identify themselves. On the other hand, no evidence of such distortion was found in the circumstances, attitudes or patterns of responses. In reviewing the results of this study the above-mentioned limitations might be taken into consideration.

One further caution might be mentioned. It must not be presupposed that police agents should all have the same philosophy, analysis or dispositional tendencies. Implicit in a professional approach is a latitude of diagnosis and treatment in which each officer uses his abilities to best effect. Until much more is known about relative effectiveness, the variability and uncertainty of human circumstances can best be handled not by book rules, but through entrusted and warranted professional responsibility. 


\section{NOTES}

${ }^{1}$ Dennis C. Sullivan and Larry J. Siegel, "How Police Use Information to Make Decisions, An Application of Decision Games," Crime and Delinquency, Vol. 18, No. 3, July, 1972.

2 James Q. Wilson, "The Police and the Delinquent in Two Cities" (unpublished manuscript), p. 37. Also see his paper, "The Police and their Problems: A Theory," Public Policy, Vol. XII, 1962, pp. 189-216.

3 Wayne R. LaFave, "The Police and Nonenforcement of the Law," Wisconsin Law Review, January, No. 1, 1962.

${ }^{4} \mathrm{~J}$. Preiss and H: Ehrlich, An Examination of Role Theory: The Case of the State Police, Lincoln: University of Nebraska Press, 1966. 


\section{BIBLIOGRAPHY}

Bodine, George, "Factors Related to Police Dispositions of Juvenile Offenders," Syracuse University Youth Development Center (paper read at annual meetings of American Sociology Association, Montreal, Canada, August, 1964).

Chicago Police Youth Division, Statement of Activities, 1960, p. 4. Goldman, Nathan, The Differential Selection of Juvenile offenders for Court Appearance, National Research and Information Center and National Council on Crime and Delinquency, 1963.

Hollingshead, August B. and Redlich Frederich C., Social Class and Mental Illness, John Wiley and Sons, Inc., New York, N.Y., 1958, p. 184 .

LaFave, Wayne R., "The Police and Nonenforcement of the Law," Wisconsin Law Review, Vol. 1962, No. 1, January, pp. 104-137, and No. 2, March, pp. 179-239.

McEachern, A. W. and Bauzer, Riva, "Factors Related to Disposition in Juvenile Police Contacts," in Malcolm W. Klein and Barbara Myerhodd, eds., Juvenile Gangs in Context: Research, Theory, and Action, University of Southern California, Youth Studies Center, Conference Report, 1963, pp. 192-210.

Myren, R. and Swanson, Lynn, Police Work with Children (Washington: U.S. Government Printing Office, 1962).

Piliavin, Irving and Briar, Scott, "Police Encounters with Juveniles," American Journal of Sociology, Vol. LXX, September, 1964, pp. 206-214.

Police Service for Juveniles, Children's Bureau Publication No. 344, U.S. Government Printing office, Washington, D.C., 1954, pp. 7-10.

Preiss, J. and Ehrlich, H., An Examination of Role Theory: A Case of the State Police, Lincoln, University of Nebraska Press, 1966.

President's Commission on Law Enforcement and Administration of Justice, Task Force Report: Police (Washington: U.S. Government Printing Office, 1967), pp. 144-204.

Sullivan, Dennis C. and Siegel, Larry J., "How Police Use Information to Make Decisions, An Application of Decision Games," Crime and De1inquency, Vol. 18, No. 3, July, 1972. 
Wattenberg, William W. and Bufe, Noel, "The Effectiveness of Police Youth Bureau Officers," Journal of Criminal Law, Criminology and Police Science, December, 1963, pp. 470-475.

Wechsler, Herbert, "The Challenge of Model Penal Code," Harvard Law Review, Vol. 65, 1952, pp. 1097, 1101-1102.

Wilkins, Leslie T., Social Deviance (Englewood Cliffs, N. J., Prentice Hall, 1965), pp. 294-304.

Wilson, James Q., "The Police and the Delinquent in Two Cities" (unpublished manuscript), p. 25. Quoted in Robert L. Peabody, "Perception of Organizational Authority: A Comparative Analysis," Administrative Science Quarterly, Vol. VI, March, 1962, pp. 477480 . 


\section{APPENDIX I}

\section{Introduction}

Police and social scientists have become increasingly interested in the information that law enforcement agents utilize when deciding the disposition of a juvenile offender. The amount of research concerned with the decision-making process in police work is, to date, limited. We invite your participation in this research study which is designed to further the already existing body of knowledge on how law enforcement personnel make their dispositional decisions on juvenile offenders. We hope to learn about the specific kinds of information you think are important when deciding what action to take on a juvenile offender. We thank you for your cooperation as it is essential to the success of this study.

\section{Instructions}

The questionnaire is divided into three sections.

Section I contains information about you as a person. Please answer $\iota$ al1 questions.

Section II contains one question regarding information categories in general.

Section III contains three case narratives with a questionnaire for each case. Please read Case I first. With each case think of yourself as the deputy involved in the case and keep in mind the suspect(s). Please answer all questions at the end of Case I before going on to Case II. While answering the questions feel free to reread any part of the case in order to help you answer the questions accurately. 


\section{Section I}

Please fill in the blanks:

1. Age on last birthday:

2. Marital status: single married separated divorced

3. Number of children:

4. Children's ages: 1. 2. 3. 5. 6. 7 8.

5. Number of months or years with MCSO: years months

6. Total number of years in police work: years

7. Are you assigned to Youth Services Unit?

yes no

8. Shift you are working at $\mathrm{ODH}$ : 1st. 2nd. $3 r d$.

9. How long have you worked this shift? years months

10. Have you completed the Understanding People Seminar?

$$
\text { yes }
$$
no

11. Circle the highest year completed in elementary or high school: $1 \quad \underline{3} \quad \underline{4} \quad \underline{5} \quad \underline{6} \quad \underline{7} \quad \underline{8} \quad \underline{9} \quad \underline{10} \quad \underline{11} \quad \underline{12}$

12. Did you graduate from high school?

yes no

13. If not, do you have a High School Equivalency Diploma? yes no

14. Circle the highest year completed in college: 12 $\underline{3} 4$

15. Did you graduate from college? yes no

16. Have you taken post-graduate courses?

yes no

17. Do you have a Master's Degree?

yes no

Please go on to Section II. 


\section{$\underline{\text { Section II }}$}

Using numbers 1 thru 10, please put in rank order the ten (10) information categories that you believe are most important in regards to the disposition of juvenile cases in general.
a. Offense
b. Attitude of suspect
c. Age
d. Sex
e. Time during shift
f. Shift
g. Location of offense
$\mathrm{h}$. Attitude of parent
i. Appearance
j. Mood of officer
k. Previous record
1. Victim involved
m. Onlookers present
n. Peer associations
o. Number of suspects
p. Local resident
q. Concealed weapon
r. Mental health of suspect

Please go on to Section III. 
Section III

\section{Case Narrative I}

\section{Allan A.}

It was a hot day. Inside Deputy D.'s car it must have been $110^{\circ}$ or hotter. The time was 6:30 P.M. Deputy D. had been on duty since 3:00 P.M., with one call after another in his district (District 5). Deputy D. was feeling sweaty and uncomfortable in his heavy uniform. He was thinking to himself, "When are the people who run this department going to realize the need for light weight uniforms and air conditioned cars?"

Deputy D. was drifting towards Fancy Dan's Restaurant at 122 and Glisan. He was hoping a cold drink would improve his spirits. The last call had not helped his mood. He had gotten his uniform dirty while checking for vehicle identification on a stolen car. The behavior of the suspects involved had made him feel nervous and anxious. As he reached Fancy Dan's he received a 12-13 (criminal mischief) call at 106 and Klicitat. The Dispatcher stated that the informant reported that two male juveniles were throwing rocks onto the freeway; both were riding bokes. "Damnit, couldn't things be quiet for fifteen minutes," Deputy D. grumbled to himself as he proceeded to the location.

He entered Klicitat at 117 th and proceeded West at moderate speed. At 108 th two male juveniles on bikes were observed coming in his direction. He slowed down to stop and as they neared the car he asked them to stop as he wanted to talk to them. At that time both juveniles increased their speed, turning South on 108th. Deputy D. made a U turn and pursued the suspects. As he reached the intersection of 108 and Fargo (two blocks away) there was no sign of the suspects. He parked the car and got out, 
as he was sure they were hiding close by. Just then, a resident of a nearby house surrounded by a tall laurel hedge escorted the two suspects out from behind the hedge and towards the officer.

Both suspects were dressed in cut-off blue jeans and tank tops. They had on tennis shoes but were without socks. Their hair was moderately long, coming down to the middle of their necks. Both appeared clean and their clothes were in good condition although somewhat soiled.

Before questioning the suspects Deputy D. explained to them their rights which they stated they understood.

In a hostile tone the older of the two protested, "I didn't do nothing." When asked why he and his friend didn $t$ stop when ordered, he answered in an insolent tone, "We didn't feel like it." When asked what they were doing in the neighborhood, he answered, "Just riding around." Deputy D. then asked what they knew about rock throwing at cars on the freeway which had just occurred in the area. In a surly tone the older boy retorted, "I told you we weren't doing nothing wrong." At this point Deputy D.'s patience was beginning to wear thin, as it was obvious that the older boy was expressing insolent and disrespectful behavior without signs of bizarreness or abnormality. He learned from the older boy that his name was Allan A., age 16, DOB 1-2-57, and from the other boy that his name was Bill B., age 15, DOB 2-3-58. Deputy D. requested a records check on both juveniles. The check was negative for both.

He received a call from the sergeant on patrol. He was parked on the freeway with a victim of the rock throwing. The victim's windshield had been shattered by a rock which had richocheted off the pavement, striking his car. Two male juveniles were observed by the victim running from 
the top of the hill as he stopped and got out of his car to investigate. The victim was sure he could identify the juveniles even though the distance separating him from them was about 200 feet.

Deputy D. gave the sergeant his present location for a rendezvous. While waiting, Deputy D. had asked to see the contents of the boys' pockets. Neither carried identification. But in the pocket of Allan A. there was a large pocket knife which appeared to exceed lawful limits. Deputy D. learned from Bill B. that both boys lived in Milwaukie, Oregon, and that Allan A. had lived in the area about two years ago. Allan A. had talked Bill B. into biking the distance to check on some old friends. Allan A. reluctantly gave his address and phone number, saying, "Why do you need to know where I live? My parents don $t$ need to know. I can take care of myself."

As the sergeant and the victim, Mr. V., arrived, the resident involved returned to his home but not before he offered the use of his phone if needed. There were no other onlookers present at this time.

Mr. V. identified, without hesitation, the two boys as those who had thrown rocks at his car. His mood was angry, saying, "You damn punks could have killed me." But he controlled his actions and needed no restraining by the officers. Mr. V.'s concern turned to the damage done to his car, saying, "What you do with these two is your business but who's going to pay for a new windshield." Deputy D. assured Mr. V. that he wait while verification of the suspects' addresses and phone numbers was made. Calling from the home of the resident involved, Deputy D. contacted the parents of Allan A. The boy's situation was explained with both parents expressing surprise and disbelief. Mrs. A. stated that Allan and his friend had been given permission to go for a bike ride earlier that day 
as they both had gotten new ten speed bikes. She had no idea of their plans to ride into Portland. Mrs. A. admitted that both she and Mr. A. had begun to worry about the boys' whereabouts. The father took the phone. He expressed his concern, saying, "We realize the seriousness of Allan's actions; there will be consequences for his behavior. Was anyone injured?" Mr. A. was relieved to learn that there were no injuries. About restitituon he said, "Please give the victim my address and phone number. We will get in touch with the other boy's parents so that the money needed to pay for the windshield will be available as soon as possible." Finally, with anxious anticipation in his volce Mr. A. asked, "What are you going to do with my son?" 
A. If you were the deputy involved in this case which one of the following dispositions on Allan A. would you make? Check only one of the decisions.

1. Warn and release at the scene.

2. Release to parents without writing a custody report.

3. Write a custody report; release juvenile on scene with follow-up notification to parents.

4. Write a custody report and release to parents at home.

5. Write a custody report and release to parents at $\mathrm{ODH}$.

6. Take into physical custody and transport to an established counseling agency other than Juvenile Court, i.e. Waverly Children's Home, Children's Services Division, etc.

7. Take into physical custody and transport to Juvenile Court. 
B. Below is a 1 ist of 18 information categories all of which were represented in the case narrative. Rate each category (High, Medium, or Low) on the basis of its importance to your disposition on the suspect, Allan A. Check only one space in each category.

\section{Information Category}

a. Offense

b. Attitude of suspect

c. Age

d. Sex

e. Time during shift

f. Shift

g. Location of offense

h. Attitude of parent

1. Appearance

j. Mood of officer

k. Previous record

1. Victim involved

m. Onlooker present

n. Peer association

o. Number of suspects

p. Local resident

q. Concealed weapon

r. Mental health of suspect

C. From the above categories, list the three most important items of information used in reaching your disposition (1ist by item letter).

1.

2.

3.

High Medium Low
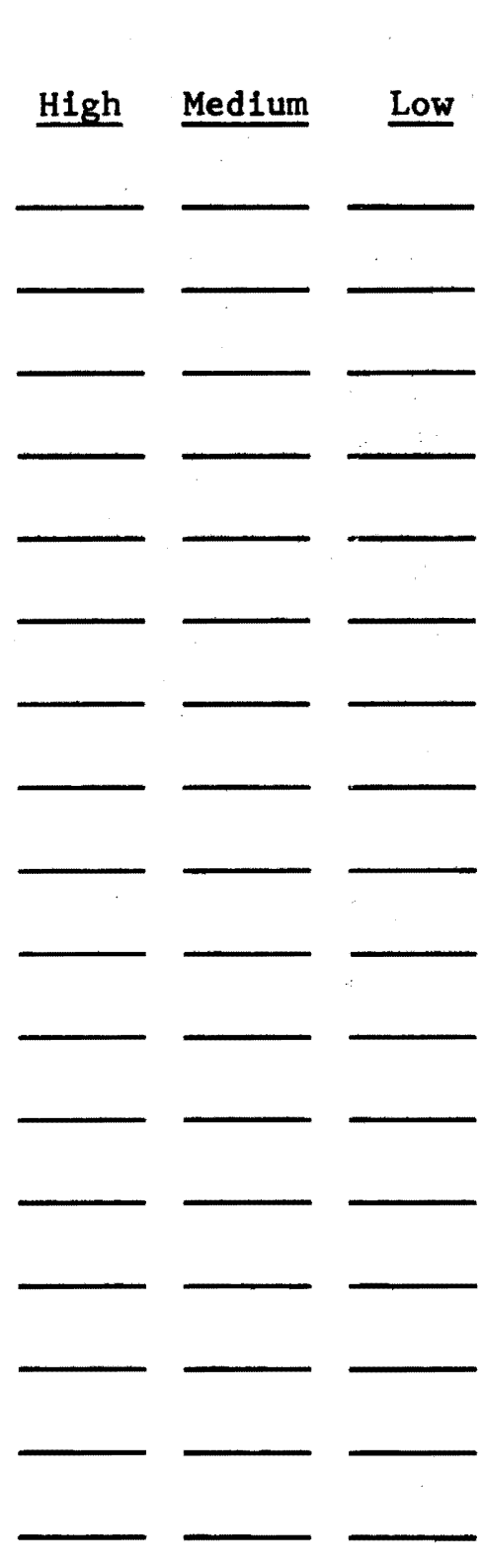

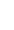


D. Describe any other item of information which was apparent to you at the scene of the incident but was not included in the above categories and which would have had an important influence on your decision. If none other exists, please indicate by writing "None" in the space below.

E. Draw a circle around the number which best indicates the degree of confidence you have in your decision in this case.

Least confident $\underline{1} \quad \underline{2} \underline{3} \quad \underline{4} \underline{5} \quad \underline{6} \quad \underline{7} \quad \underline{8} \quad \underline{9} \quad \underline{10}$ Most confident

Please check to be sure you have answered all questions. Please go on to the next case. 


\section{Case Narrative II}

John B.

At 11:30 PM Deputy E. was cruising in his patrol car. He was reminding himself of all of the things he should have said to the lieutenant who confronted him at roll call for his low merit rating. Deputy E. felt the lieutenant should have done this in private instead of in front of all of the guys. He also felt that his merit rating wasn't much lower than many of the other deputies.

At 11:35 PM a call came through to investigate a 12-13 (criminal mischief) at 14 Flavel Avenue. Deputy E. thought to himself, "The people in this damn neighborhood are always beefing about something." When he arrived at the address an irate, elderly lady complained that the youngest $B$. boy had pulled up all of her prize rose bushes and that his two older brothers just stood by and laughed while he did it.

When Deputy $\mathrm{E}$. questioned her regarding how she knew it was the youngest B. boy who had committed the act, she answered, "I saw him through the window!" She went on to explain that when her dog had barked she ran to the window to see what was going on. The street light helped her clearly see "that B. kid doin it." She turned on the porch light, opened the door and yelled at the kids. She said they looked up at her, laughed and ran toward their house. She saw them go inside. She did not attempt to call the parents as she knew from past experience that it would do no good. According to Mrs. C., "The parents are worse than the kids!"

Mrs. C., the complainant, began to chide Deputy E. for asking her so many questions. She showed her annoyance by saying, "Why don't you stop asking me so much stuff and go over there and arrest the hoodlums?" 
Deputy E. walked over to the house where, according to Mrs. C., the boys lived. There were two old cars parked in the front yard. One car had no fenders or headlights and the other had a flat tire. The yard was littered with various objects. In the dark he almost fell over a piece of pipe. Deputy E. walked onto the porch and knocked at the door. A few moments later a man whose breath smelled of alcohol opened the door. The man looked directly at Deputy E, and in an angry tone he said, "What the hell do you want?" Deputy E. identified himself. He explained that there had been a complaint made against the $B$. boys and that he was there to investigate the matter. He asked if the boys lived at this address. The man replied, "Yeah." Deputy E. asked if he might come in and discuss the problem. With some reluctance and hesitation the man agreed to allow Deputy E. to enter the room. Deputy E. asked the man if he was the boys' father. The man replied, "Hell No! My name is Mr. G. The kids belong to my wife." Deputy E. asked if he might talk with the boys. Mr. G. said, "Yeah, sure I don't care." He called the boys into the room. As the boys entered the room Deputy E. noticed that their appearance reflected the general conditions of the room--dirty, disheveled, and odorous.

Deputy E. proceeded by asking the boys their names and ages. The oldest boy stated that his name was Mark, and that he was 15 years old. His date of birth was 6-10-58. He spoke clearly, distinctly and politely. Deputy $E$. then asked the next boy his name and age. This juvenile responded angrily. He slamed his fist against the chair, saying, "My name is James; I am 14; my date of birth is May 15, 1959, and cop that's al1 I'm goin to tell you." 
The third boy was standing quietly in the corner of the room with his head bowed. When Deputy E. asked his name and age, his response was a burst of laughter. His stepfather reacted by rushing over to the boy and slapping him across the face. This action made the oldest boy, Mark, grimace. Mark turned to Deputy E. and explained that his younger brother didn't mean anything when he laughed. Mark went on to say that when his brother got nervous or upset he usually acted "funny." Mark informed Deputy E. that his youngest brother's name was John. He was 13 years old and was born January $13,1960$.

The mother appeared groggy as she walked into the room. John immediately ran to her. She shoved him aside and said, "What the hell is this cop doin here?" Before Deputy E. had a chance to explain, the husband told her what happened. In a rage she declared, "The whole damn neighborhood will know the cops are here. That nosey old bitch is always causing trouble and accusing my kids of stuff they didn't do. My kids are good kids; they never do anything really wrong, just stuff all kids pull. I am sick and tired of the lousy cops harassing my boys all the time. If you cops were out looking for criminals instead of picking on poor kids, decent people like myself might be safer on the streets at night."

Deputy E. felt himself becoming angry. Nevertheless, he patiently waited until she stopped talking. He explained that he would appreciate their cooperation by allowing him to question the boys so that the matter could be cleared up. The mother objected, saying, "Hell No! My kids ain't no criminals!" The stepfather interrupted her, saying, "Shut your face and let the deputy ask the kids what happened." Reluctantly, she agreed. 
Deputy $E$. informed the boys of their rights and they stated they understood them. Since John was the boy accused of pulling up the bushes, Deputy E. first directed questions toward him. Again, John seemed unable to respond. He just sat on the floor, staring at the wall. It appeared to Deputy E. that the boy's behavior was abnormal and that he was not expressing insolent or defiant behavior. Since he could not get a response from John, Deputy E. asked Mark to explain what had happened. Mark stated remorsefully that he and his brother James thought it would be fun to do something to make the "old lady" mad. They encouraged John to pull up the rose bushes. Neither he nor James touched the flowers because they didn't want to get in trouble for doing it. Mark was sorry now that they had done it. At this, the stepfather began shaking his fists at the boys, but said nothing.

Deputy E. asked Mr. G. if he might use the phone. Mr. G. said, "Okey, but no long distance calls." A record check revealed that all three boys had previous records. On several occasions they were picked up for curfew violations. They had also been referred for vandalism. James had been apprehended for shoplifting. John had a history of setting fires to vacant lots.

When Mr. G. came back from the kitchen with a fresh can of beer in his hand he said to Deputy E., "What are you going to do with that dumb kid, John?" 
A. If you were the deputy involved in this case which one of the following dispositions on John B. would you make? Check only one of the decisions.

1. Warn and release at the scene.

2. Release to parents without writing a custody report.

3. Write a custody report; release juvenile on scene with follow-up notification to parents.

4. Write a custody report and release to parents at home.

5. Write a custody report and release to parents at ODH.

6. Take into physical custody and transport to an established counseling agency other than Juvenile Court, i.e. Waverly Children's Home, Children's Services Division, etc.

7. Take into physical custody and transport to Juvenile Court. 
B. Below is a list of 18 information categories all of which were represented in the case narrative. $R$ te each category (High, Medium, or Low) on the basis of its importance to your disposition on the suspect, John B. Check only one space in each category.

\section{Information Category}

a. Offense

b. Attitude of suspect

c. Age

d. Sex

e. Time during shift

f. Shift

g. Location of offense

h. Attitude of parent

i. Appearance

j. Mood of officer

k. Previous record

1. Victim involved

m. Onlooker present

n. Peer association

o. Number of suspects

p. Local resident

q. Concealed weapon

r. Mental health of suspect

C. From the above categories, list the three most important items of information used in reaching your disposition (list by item letter). 1.

2 .

3.

\section{High Medium Low}
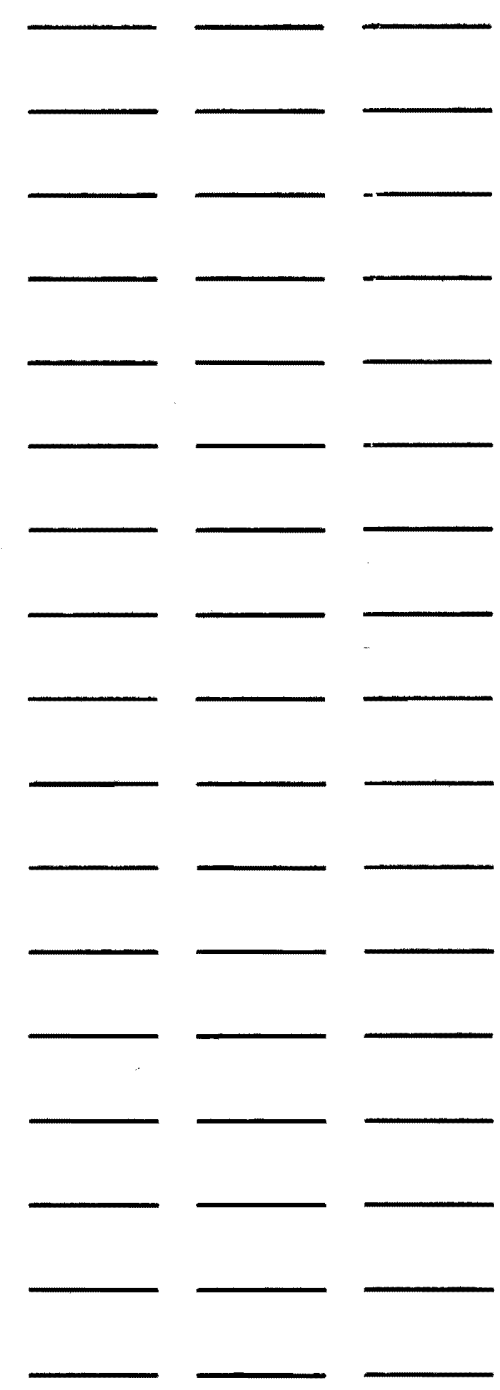

-
item letter). 
D. Describe any other item of information which was apparent to you at the scene of the incident but was not included in the above categories and which would have had an important influence on your decision. If none other exists, please indicate by writing "None" in the space below.

E. Draw a circle around the number which best indicates the degree of confidence you have in your decision in this case.

Least confident $\quad \underline{1} \quad \underline{2} \quad \underline{3} \quad \underline{4} \quad \underline{5} \quad \underline{6} \quad \underline{7} \quad \underline{8} \quad \underline{9} \quad \underline{10}$ Most confident

Please check to be sure you have answered all questions.

Please go on to the next case. 


\section{Case Narrative III}

Jane D.

At 1:00 PM on February 16, 1973, Deputy T. had apprehended a wanted burglary suspect. At 1:20 PM he transported the suspect to Rocky Butte Jail. At 2:20 PM booking procedures had been completed. On the way back to Operations Division Headquarters to go off duty, Deputy T. was feeling pretty satisfied with himself. This suspect had been on the "wanted" list for some time. He no doubt had scored some points by "bucketing" this guy. At 2:40 PM he received a call. He was dispatched to the high school in his district to investigate a criminal mischief incident.

Upon arrival, Deputy $T$. was advised by Mr. S., the Principal, that a student, Jane D., had been observed by another student destroying school property. Deputy T. asked if he could speak with the student who had observed the act. Mr. S. directed Deputy $T$, to his office where Charles W. was waiting. Charles W. told Deputy T. that as he was passing the Science Laboratory he heard a "crash." He opened the door to investigate the noise and saw Jane D. throw a microscope onto the floor. He also observed several other pieces of broken microscopes on the floor of the room. Charles W. continued that when Jane saw him she ran out of the room. The boy stated that he chased her but she ran into the girls' rest-room. Charles then ran to the Principal's office and reported what had occurred.

Charles W. was dismissed. Mr. S. and Deputy T. continued discussing the case. Mr. S. stated that when Charles W. reported to him what had happened he and his secretary ran to the girls' rest-room. His secretary entered the rest-room and saw Jane attempting to climb out of the window. 
The secretary said that she grabbed the girl and after a brief struggle managed to subdue Jane and convince her to come to the office. Mr. S. said that Jane was now in the Vice Principal's office with his secretary. Mr. S. told Deputy $T$. that when he inspected the damage he was "really angry." Five miscroscopes, valued at over $\$ 1000$, were completely destroyed. Mr. S. stated that restitution would have to be made for the damage. Deputy $T$. asked the Principal if Jane had ever done anything like this before. Mr. S. said, "No, Jane was usually a quiet girl. She had few friends and never had been any problem at school." Mr. S. said that in consideration of her previous record of good behavior he only intended to suspend her for three days. He told Deputy $T$. that beyond this action he would support Deputy $T$. in whatever decision he decided to make. Deputy $T$. then requested to speak with Jane D. The Principal escorted Deputy $T$. to the office where Jane was waiting. Upon entering the office, Deputy T. noticed the suspect's appearance. She had long, blonde hair that appeared greasy and unkempt. She wore blue jeans which were torn at the lower seams and soiled with what seemed to be food stains. Her faded purple tee shirt revealed old perspiration marks. She wore sandals and no stockings. She was about $5^{\prime} 8^{\prime \prime}$ and weighed around 150 pounds.

In the presence of Mr. S., Deputy T. began preliminary questioning. Jane's date of birth was 1-12-57. Her home address was 8642 Russell Ave. Her father was a construction worker. Her mother was a housewife. Deputy $T$. advised Jane $D$. of her rights and the subject declared that she understood them. Deputy $T$. confronted the girl with the accusation made against her and asker her if she had committed the act. After a few moments she tearfully admitted breaking the microscopes. She stated 
angrily, "I would have gotten away with it too, if it hadn't been for Charlie narcing on me!" Further investigation revealed that she did it because she was angry at her science teacher and some of the students. She tearfully said, "The teacher embarrassed me in front of the whole class. He said that I looked like a slob and should try taking a bath once in awhile." She went on to say that later in the period some of the students began "bugging" her about her appearance. She said, "At first, it just made me feel real bad but then $I$ got angry and decided after class was over I would break the microscopes and get even with all of them." Mr. S. quietly explained to Jane the cost of the damage and what the microscopes meant to the school. She looked surprised and then concerned. She put her head down and stated, "I'm sorry, I didn't know they cost so much. I guess I just lost control of myself."

A records check revealed that in the past two years Jane $D$. had been involved in a series of offenses outside of school. On one occasion she was caught shoplifting. On three occasions she was apprehended for possession of marijuana. She had been classified twice as a runaway. Having been previously summoned to the school by Mr. S., Jane's parents arrived. Her father wore clean work clothes. Her mother was neatly and modestly dressed. Both appeared to be in their late forties or early fifties. When they entered the room, Jane turned away from everyone and stood staring out of the window. Neither did they say anything to her nor did she say anything to them. Deputy $T$. informed the parents of the situation. They seemed unable to speak. Jane's mother began to cry. Her father shook his head and apologized for all of the trouble. He then turned to Deputy T. and quietly said, "I'm so confused; I don't know what to do with her. Tell me, officer, what are you going to do with her?" 
A. If you were the deputy'involved in this case which one of the following dispositions on Jane D. would you make? Check only one of the decisions.

1. Warn and release at the scene.

2. Release to parents without writing a custody report.

3. Write a custody report; release juvenile on scene with follow-up notification to parents.

4. Write a custody report and release to parents at home.

5. Write a custody report and release to parents at $\mathrm{ODH}$.

6. Take into physical custody and transport to an established counseling agency other than Juvenile Court, i.e. Waverly Children's Home, Children's Services Division, etc.

7. Take into physical custody and transport to Juvenile Court. 
B. Below is a list of 18 information categories all of which were represented in the case narrative. Rate each category (High, Medium, or Low) on the basis of its importance to your disposition on the suspect, Jane D. Check only one space in each category.

Information Category

a. Offense

b. Attitude of suspect

c. Age

d. Sex

e. Time during shift

f. Shift

g. Location of offense

h. Attitude of parent

i. Appearance

j. Mood of officer

k. Previous record

1. Victim involved

m. Onlooker present

n. Peer association

o. Number of suspects

p. Local resident

q. Concealed weapon

r. Mental health of suspect

C. From the above categories, list the three most important items of infor-

mation used in reaching your disposition (1ist by item letter).

\section{High Medium Low}
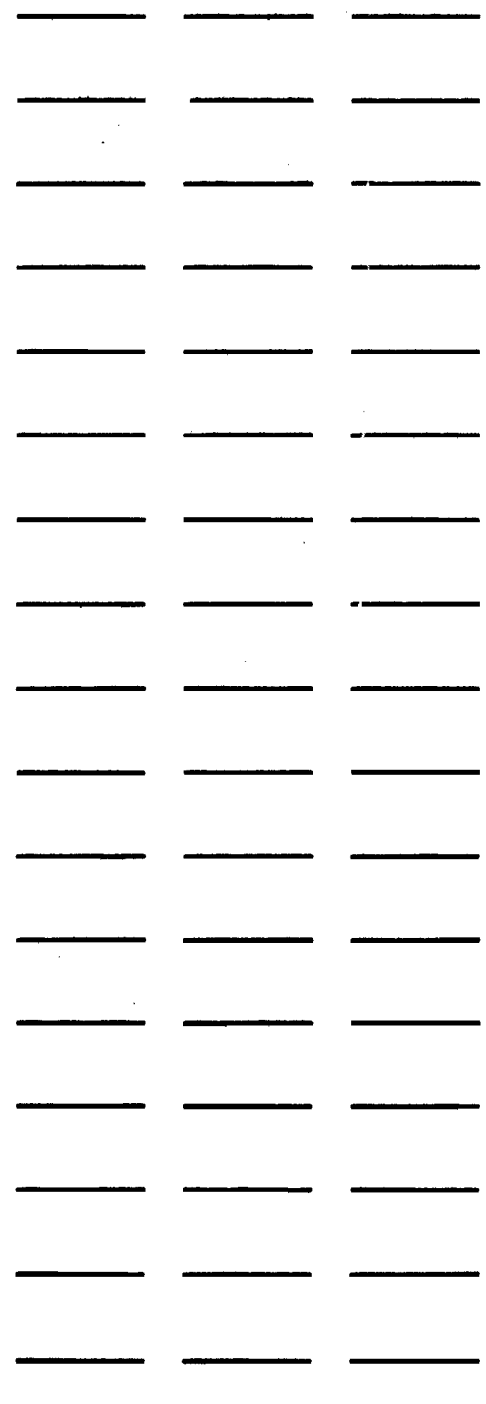

(1)

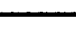

2.

3. 1 . 
D. Describe any other item of information which was apparent to you at the scene of the incident but was not included in the above categories and which would have had an important influence on your decision. If none other exists, please indicate by writing "None" in the space below.

E. Draw a circle around the number which best indicates the degree of confidence you have in your decision in this case.

Least confident $\quad \underline{1} \quad \underline{2} \quad \underline{3} \quad \underline{4} \quad \underline{5} \quad \underline{6} \quad \underline{7} \quad \underline{8} \quad \underline{9} \quad \underline{10}$ Most confident

Please check to be sure you have answered all questions. 